\title{
Nové zberové nálezy rímsko-provinciálnych spôn z južnej Moravy v zbierkach Regionálneho múzea v Mikulove
}

\section{New prospection finds of provincial roman brooches from south Moravia collected in Regional Museum in Mikulov}

\section{Patrik Urban}

\begin{abstract}
Abstrakt
Článok prezentuje súbor 67 rímsko-provinciálnych spôn z oblasti južnej Moravy, ktoré sú uložené v Regionálnom múzeu v Mikulove. Spony sa získali zbermi detektormi kovov, ktoré uskutočnili pracovníci múzea, ako aj amatéri v rokoch 2003 až 2019. Príspevok sa venuje typologickej analýze spôn, ich chronologickému zaradeniu a geografickému rozšíreniu v sledovanom regióne povodia rieky Dyje na základe doterajšieho stavu bádania.
\end{abstract}

\section{Kl'účové slová}

Provinciálne spony, doba rímska, detektorový prieskum, Južná Morava, provincie, markomanské vojny

\begin{abstract}
The article presents collection of 67 provincial roman brooches acquired and collected in Regional Museum in Mikulov, South Moravia, Břeclav district. Brooches were found during continuous metal detecting survey undertaken by Museums employees and non-academic amateurs since 2003 up until 2019. The aim of this article is to examine presented brooches and their typological, chronological, and spatial relation with surrounding landscape within the region of river Dyje (Thaya) during the Roman period.
\end{abstract}

\section{Key words}

Provincial Roman Brooches, Roman period, Metal detector prospection, South Moravia, Roman provinces, Marcomannic wars 


\section{1. Úvod}

Predkladaná štúdia ${ }^{1}$ predstavuje súbor doposial nepublikovaných rímsko-provinciálnych spôn doby rímskej zo zbierok Regionálneho múzea v Mikulove, okr. Břeclav² (příloha 1). Je výstupom autorovej bakalárskej práce obhájenej na Ústave archeologie a muzeologie Filozofickej fakulty Masarykovej Univerzity v Brne v roku 2020. Cielom práce bola dokumentácia a následná analýza a syntéza vybraných spôn a ich nalezísk v kontexte osídlenia doby rímskej a rímskych vojenských táborov v Podyjí.

\subsection{Charakteristika súboru a kritika prameňov}

Súbor obsahuje 67 spôn obdržaných v Regionálnom múzeu v Mikulove (d’alej len RMM) medzi rokmi 2003 a 2019. Najviac spôn pochádza z katastrálneho územia obce Lanžhot a Kostice v počte 25 kusov (Graf 1). Devät spôn evidujeme z katastra obce Ladná, po 5 exemplárov z obcí Kostice, Mikulov, Milovice a Rakvice. Tri spony sa našli na lokalite Mušov - Na pískách, po dvoch sponách sme evidovali lokality Břeclav, Charvatská Nová Ves, Hrušky, Mušov - Burgstall a Podivín, po jednej z obcí Dolní Bojanovice, Nové Mlýny, Pasohlávky, Pohořelice a Přítluky. Vo všetkých prípadoch ide o zbery detektormi kovov.

Z celkového počtu 67 kusov nemá presné GPS koordináty 30 spôn. Pät spôn nemá určenú GPS, no má aspoň približnú trat̉ a 3 sponám chýbajú ako GPS koordináty, tak katastrálne určenie trate (vid' sumarizačnú tabul'ku spôn). Spony z lokalít s preukázanou vojenskou prítomnostou Rimanov predstavujú problematickú časť štúdie. Ani jedna zo spôn nemá presne zamerané GPS údaje, čo neumožňuje presné priestorové analýzy, a samé o sebe predstavujú nález bez presnej lokalizácie, je rovnako na mieste pochybovat’ o ich skutočnom nájdení na uvedených lokalitách. Z katastra obce Rakvice máme z piatich spôn zameranú iba jednu.

Najpočetnejšou skupinou spôn sú výrazne členené spony v počte 29 kusov (Graf 2). Nasleduje 24 kolienkovitých spôn, 4 spony s vidlicovitým lúčikom, 3 panónske trúbkovité spony, 2 zvieracie spony a 2 doštičkovité spony (Tab. 1-3). Po jednom exemplári je zastúpená šarnierová spona a emailová spona (Tab. 1). Jediné dve spony, ktoré sa zachovali celé sú kolienkovitá spona z Ladné, polohy „Kerchovka/Kerchovská“ (Obr. 5: 1) a výrazne členená spona z Dolních Bojanovic, „Nivky u starého rybníka“ (Obr. 1: 4).

\section{Typológia vybraných spôn}

\subsection{Spony západnej proveniencie}

\subsubsection{Vojenské spony}

Sú jednoduché jednodielne spony typu Almgren 15 , ktoré ich početný výskyt vo vojenských kontextoch dostali názov „Soldatenfibeln“ (Peškař 1972, 88). Ich drôtený, resp. tyčinkovitý lúčik je nepravidelne klenutý, majú spodné vinutie tvorené 4 závitmi, po dvoch na každej strane, plný zachycovač má lichobežníkový alebo štvorcovitý tvar.

Na území rímskych provincií sú dané spony zastúpené v Porýní na limitných lokalitách. Len na lokalite Colonia Ulpia Traiana sa našlo 341 vojenských spôn (Boelicke 2002, 19-41). E. Pateková (1942, 130) spájala ich výskyt v Podunajsku s presunmi légií počas vlády cisára Domitiana. Podla S. Cocişa (2004, 255, PL. 1) v Dácií patria do obdobia po Trajánovi a dáckych vojnách. E. Riha $(1979,60)$ ich datuje od včasného klaudiovského obdobia s najväčším výskytom práve v období vlády Domitiana. Pretrvávajú a vyznievajú až v hadriánovskom období (Jilek-KučaSojková 2011, 251, Tab. II: 2). 


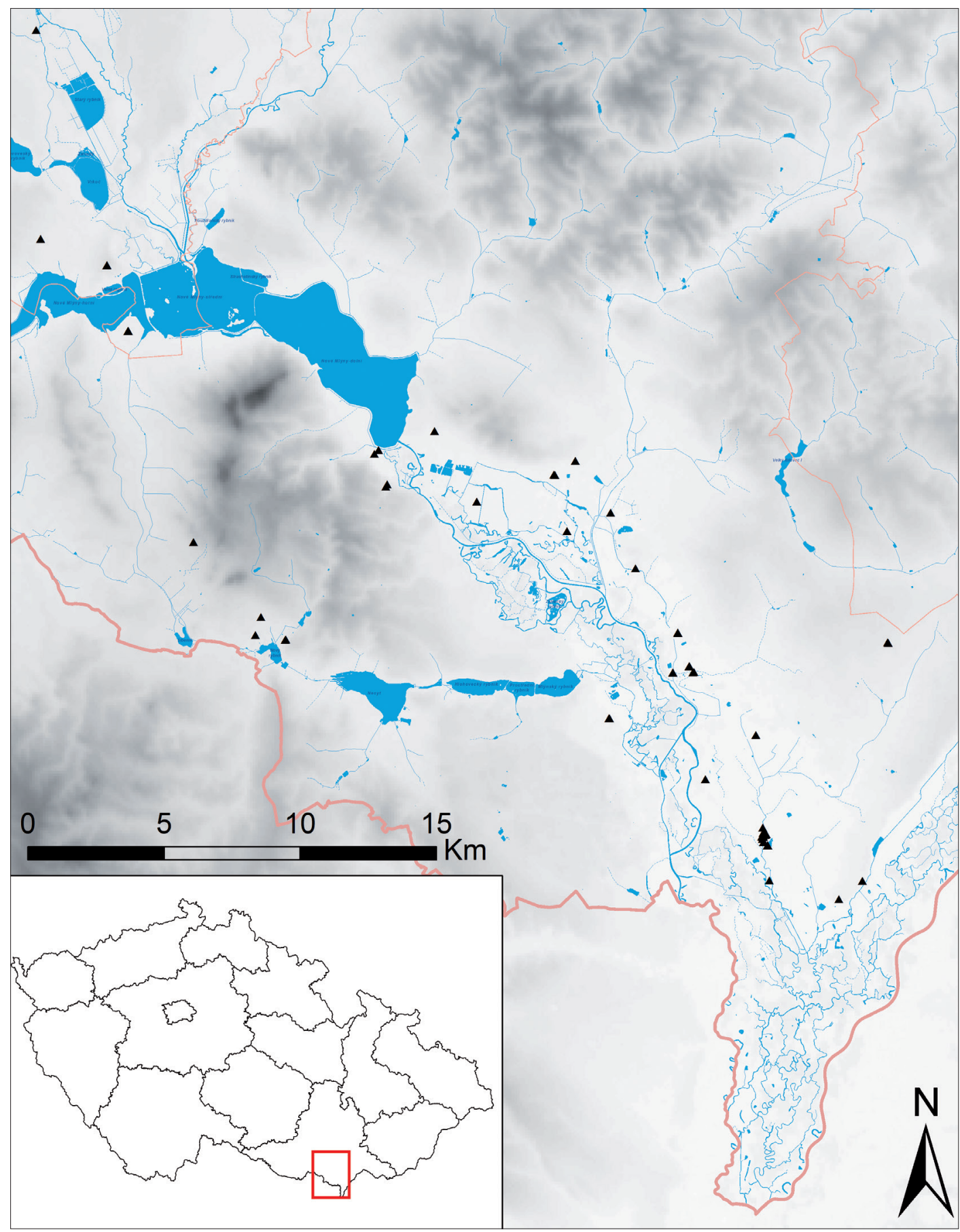

Mapa 1: Distribúcia skúmaných spôn v článku.

Map 1: Spatial distribution of finds of roman brooches mentioned in our article. 


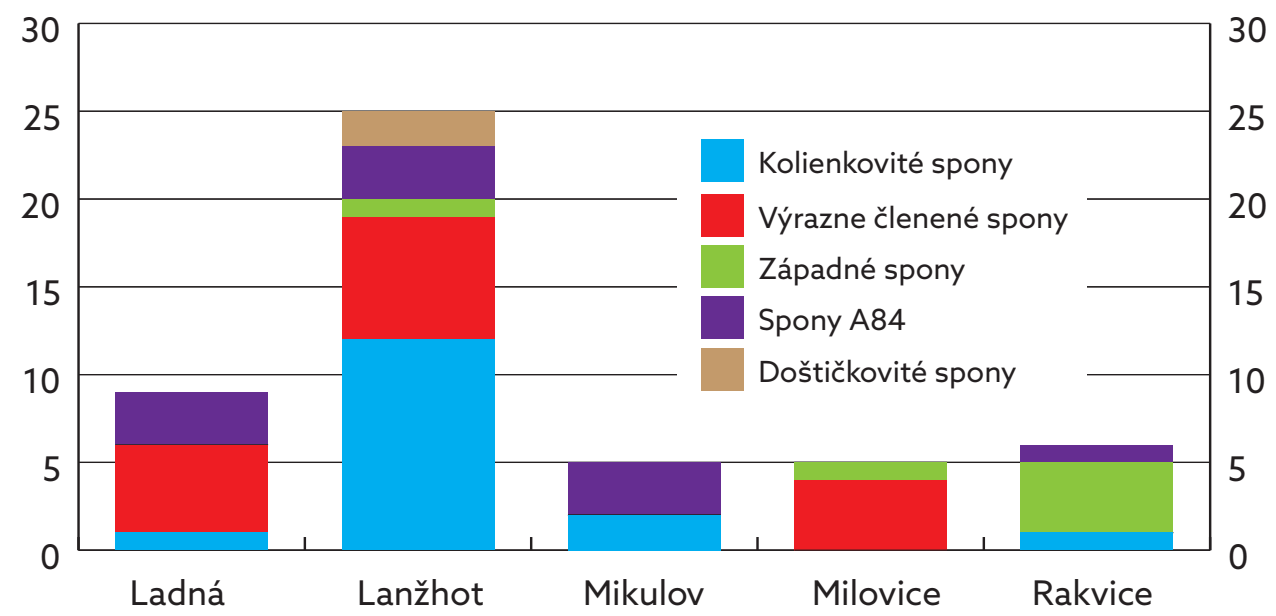

Graf 1: Zastúpenie spôn na lokalitách s vyššou hustotou nálezov.

Graph 1: Quantity of different types of roman brooches found at selected locations.

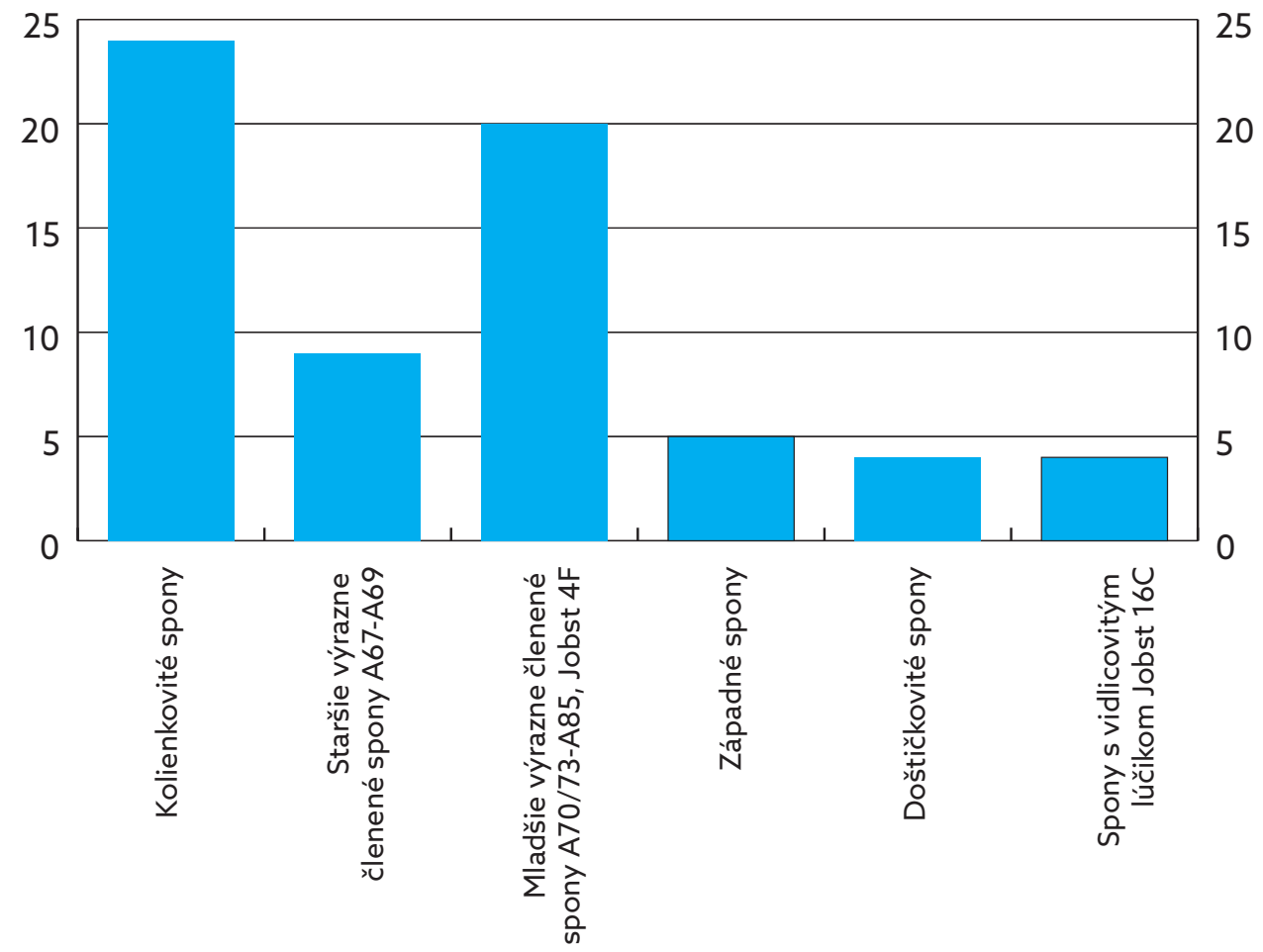

Graf 2: Kvantitatívne zastúpenie skupín spôn.

Graph 2: Quantity of roman brooches finds. 

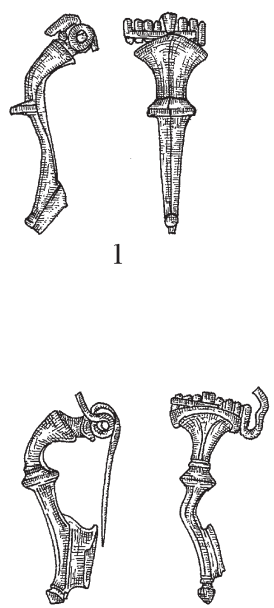

4

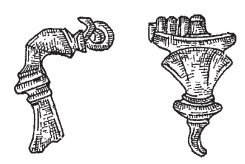

7
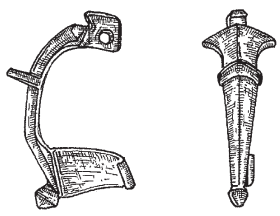

10
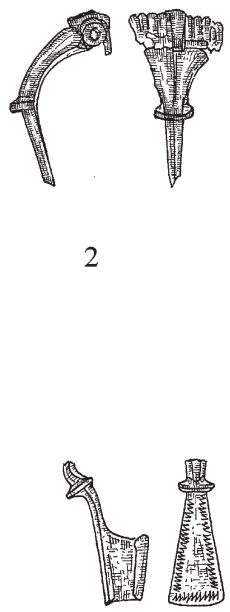

5
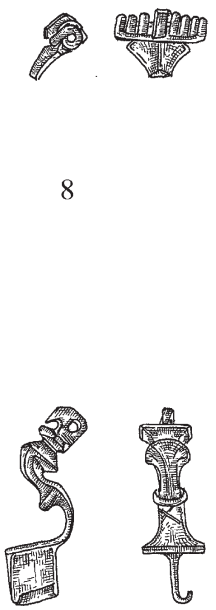

11

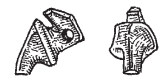

14
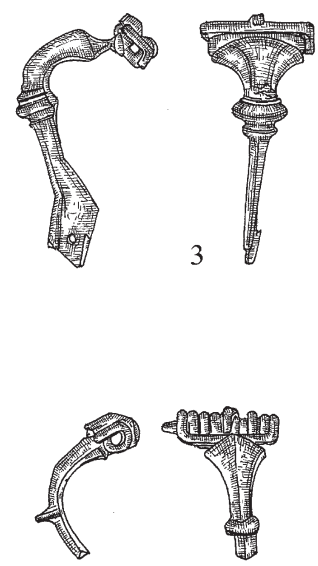

6
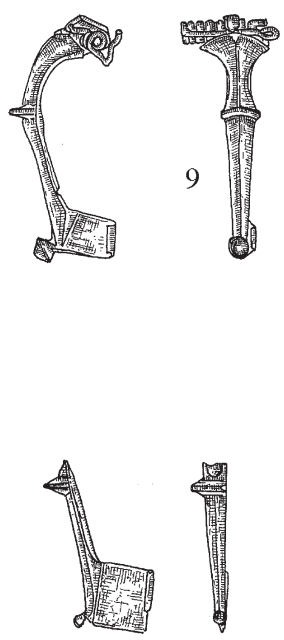

12
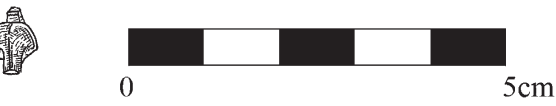

$5 \mathrm{~cm}$

Obr. 1: Výrazne členené spony, 1 - Kostice, 2, 7, 8 - Ladná, 3, 5, 9-14 - Lanžhot, 4 - Dolní Bojanovice, 6 - Mikulov Fig. 1: Strongly profiled brooches. 

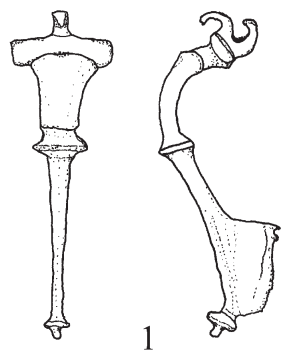

$\sum \sum_{0}^{3}$

4

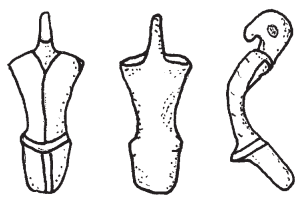

7
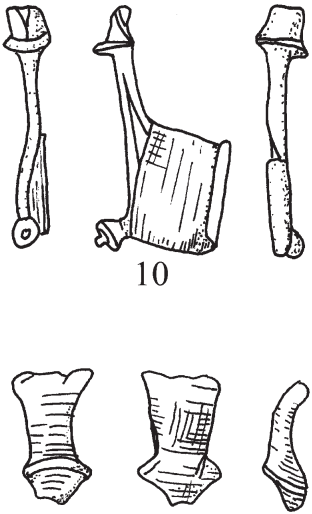
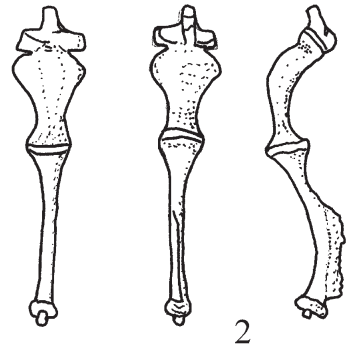

2

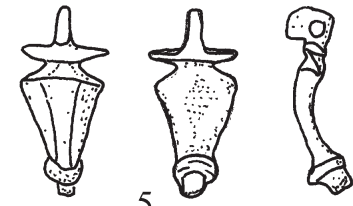

5
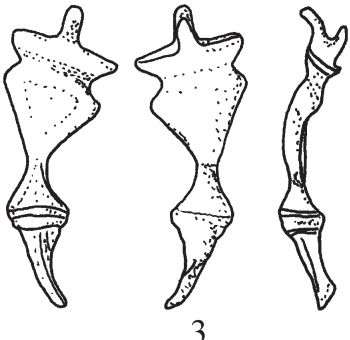

3

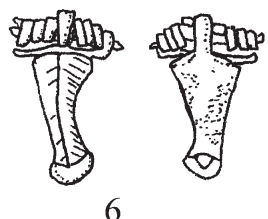

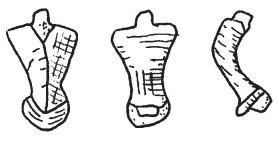

8
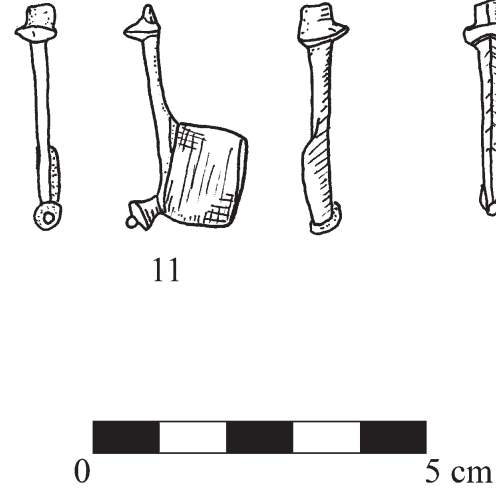

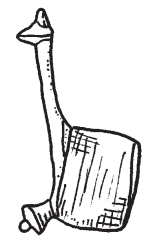

11

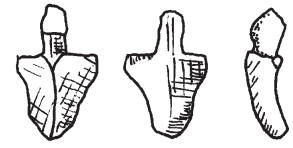

9
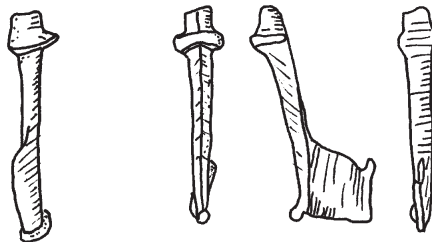

12

Obr. 2: Výrazne členené spony, 1, 4, 9 - Ladná, 2, 10 - Milovice; 3 - Př́tluky; 5 - Nové Mlýny; 6, 7 - Mikulov; 8 Rakvice; 11 - Lanžhot; 12, 13 - Hrušky.

Fig. 2: Strongly profiled brooches. 


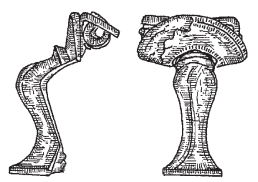

1

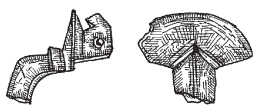

4

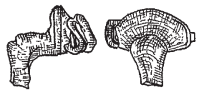

7

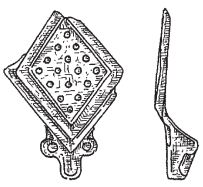

12

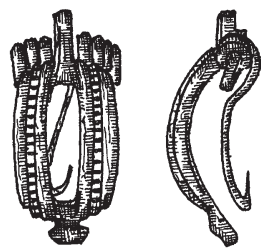

16

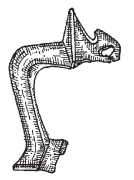

2

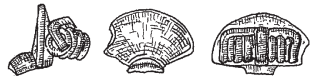

5

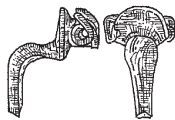

8

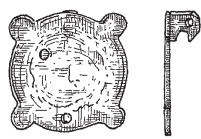

13

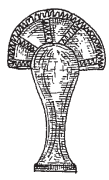

9
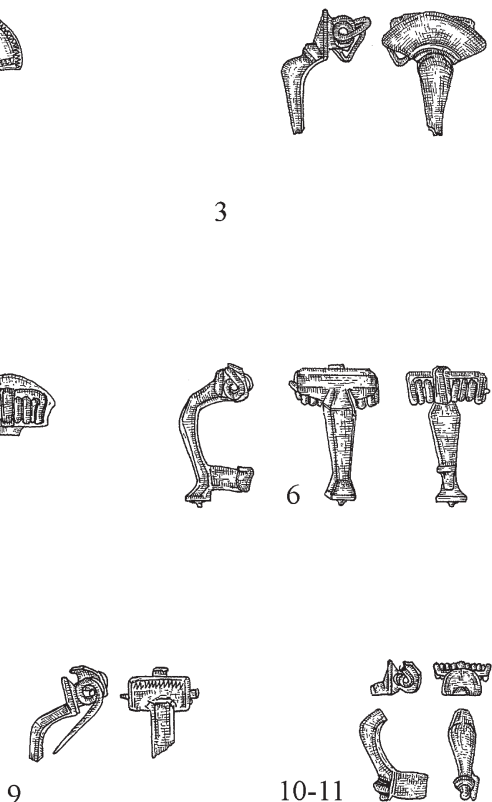

A110.

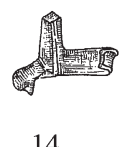

14

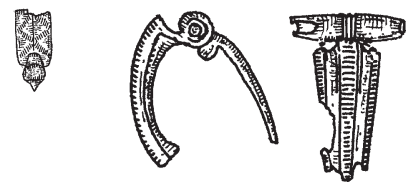

15

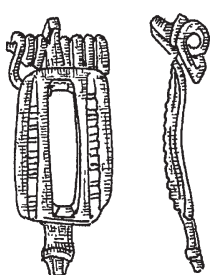

17

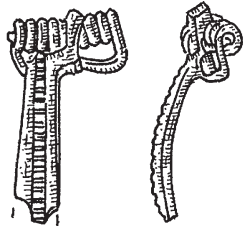

18

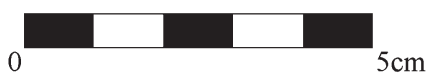

Obr. 3: 1-11 - Kolienkovité spony, 12, 13 - Doštičkovité spony, 14 - zvieracia spona, 15 - šarnierová spona, 16-18 - spony typu Jobst 16C; Lokality - 1, 2, 13 - Kostice, 3, 6-11, 14 - Lanžhot, 4, 12 - Břeclav, 15 - Charvatská Nová Ves, 16-18-Rakvice.

Fig. 3: Knee brooches. 
1
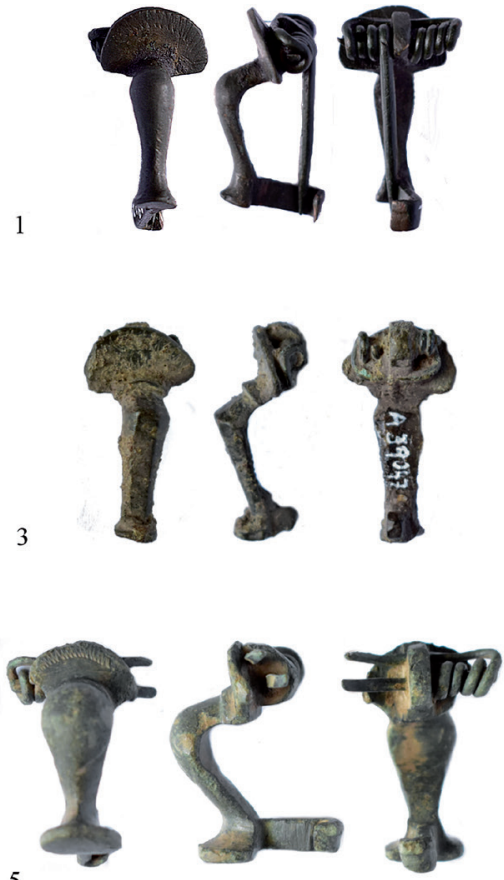

$$
5
$$
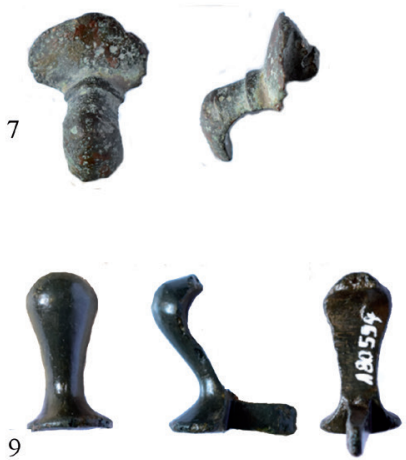

11
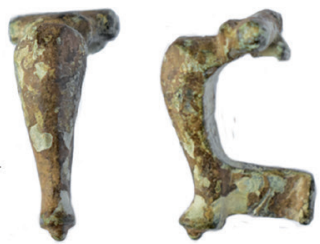

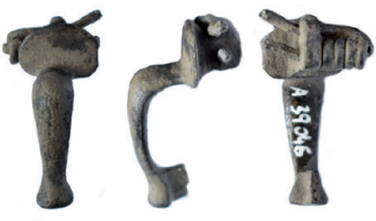

2

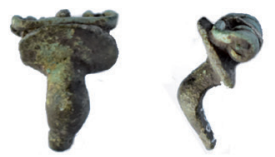

4

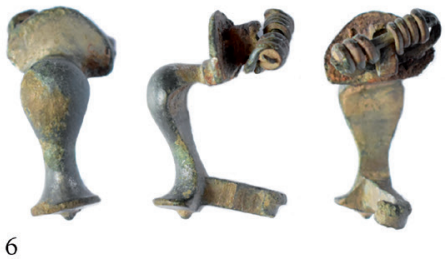

6

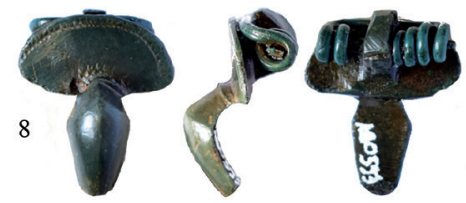

10
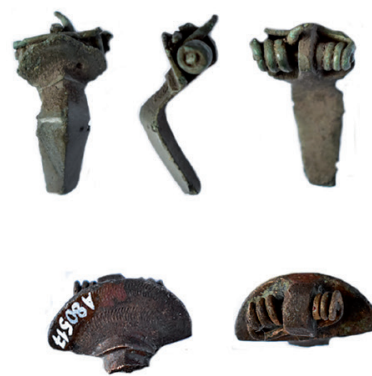

12

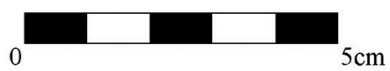

Obr. 4: Kolienkovité spony, Lokality: 1 - Ladná, 2-4 - Lanžhot, 5, 6- Mušov - Na pískách, 7 - Pasohlávky, 8, 9 Mušov - Burgstall, 10, 11 - Mikulov, 12 - Rakvice.

Fig. 4: Knee brooches. 

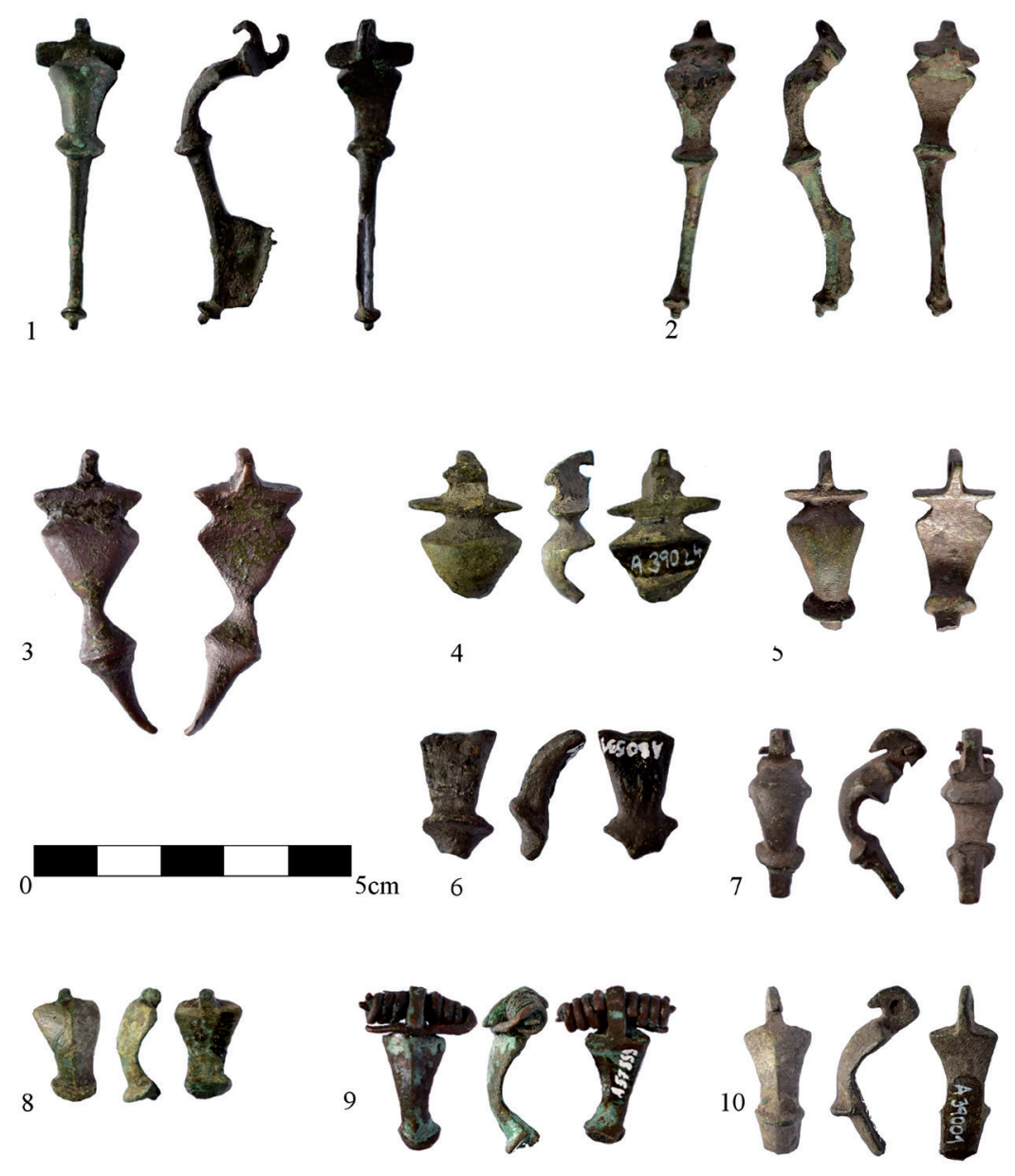

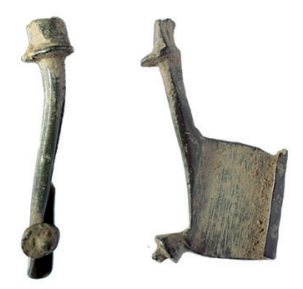

11

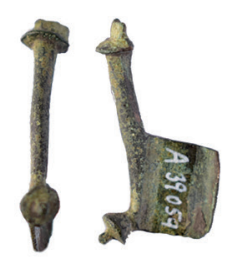

12

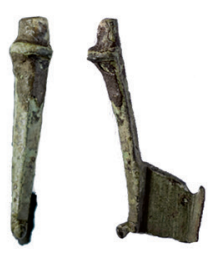

13

Obr. 5: Výrazne členené spony, Lokality: 1, 4 - Ladná, 2, 11 - Milovice, 3 - Př́tluky, 5 - Nové Mlýny, 6, 13 - Hrušky, 7 - Milovice, 8 - Rakvice, 9, 10 - Mikulov, 12 - Lanžhot.

Fig. 5: Strongly profiled brooches. 

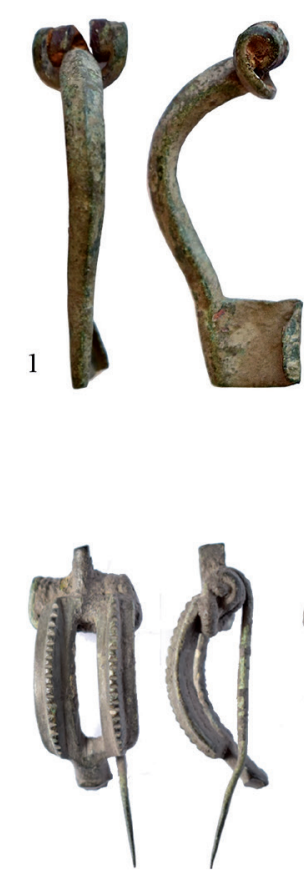

3
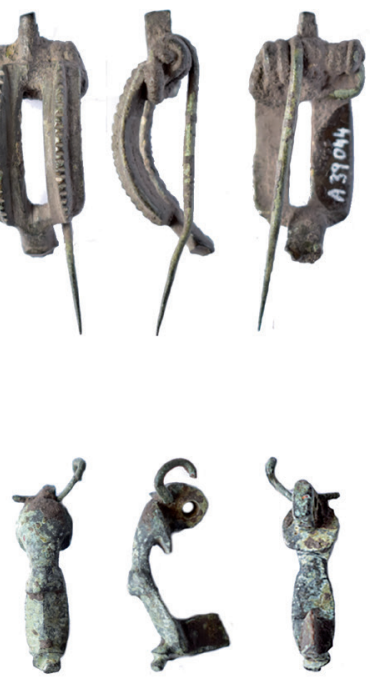

6
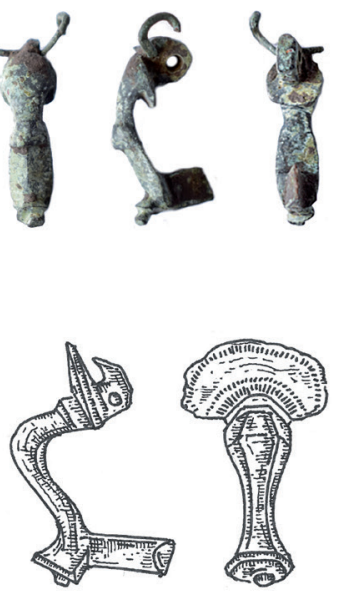
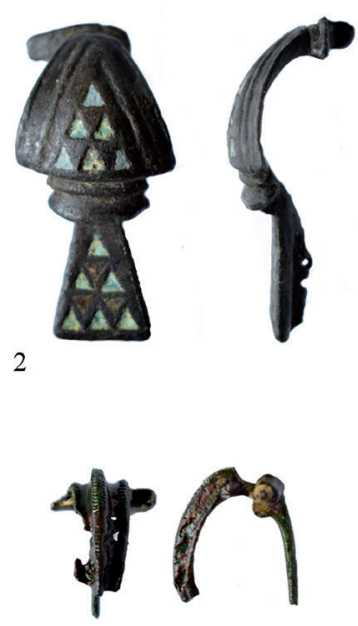

4

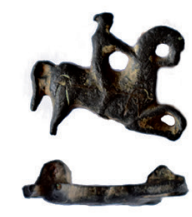

5

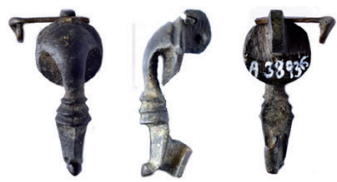

7

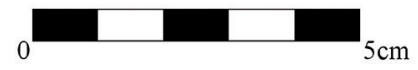

Obr. 6: 1 - Vojenská spona typu A15, 2 - Emailová spona Exner I 32, 3 - spona typu Jobst 16C, 4 - spona typu Riha 5.9, 5 - spona typu Riha 7.25, 6, 7 - Panónske trúbkovité spony typu A85, 8 - Kolienkovitá spona typu Jobst 13E; Lokality - 1 - Milovice, 2 - Podivín, 3 - Kostice/ Lanžhot, 4 - Charvatská Nová Ves, 5 - Mušov - Na pískách, 6 - Milovice; 7 - Pohořelice, 8 - Charvatská Nová Ves.

Fig. 6: Western provincial roman brooches. 


\begin{tabular}{|l|c|l|}
\hline \multicolumn{1}{|c|}{ Typ spony } & Počet & \multicolumn{1}{c|}{ Lokality } \\
\hline Almgren 15 & 1 & Milovice \\
\hline Riha 5.9 & 1 & Charvatská Nová Ves \\
\hline Riha 7.12 & 1 & Lanžhot/ Kostice \\
\hline Riha 7.17 & 1 & Břeclav \\
\hline Riha 7.22 & 1 & Lanžhot/ Kostice \\
\hline Riha 7.25 & 1 & Mušov - Na pískách \\
\hline Jobst 16c & 4 & Lanžhot/ Kostice (1), Rakvice (3) \\
\hline Exner I 32 & 1 & Podivín \\
\hline
\end{tabular}

Tab. 1: Spony západnej proveniencie, doštičkovité a emailové spony.

Chart 1: Western roman brooches, plate brooches and enamelled brooches.

V skúmanom súbore je zastúpený jediný exemplár z Milovic, z polohy „Bulharsko“ (Obr. 6: 1). Je to jednodielna bronzová spona typu Almgren 15 so spodným vynutím s dížkou $5,5 \mathrm{~cm}$, ktorej chýba ihla. Analógiami sú spony z Velatíc a Prosiměric (Jilek 2009c; Jilek-Kuča-Sojková 2011, 251, Tab. II: 2). Sponu možno rámcovo datovat od fázy B1c až B2a (Peškař 1972, 89).

\subsection{2 Šarnierové spony typu Riha 5.9}

Sú charakteristické klenutým lúčikom deleným stredovým rebrom (Riha 1979, 133). Pre tieto spony je typické pozinkovanie (Riha 1979, 134). Podobne ako iné šarnierové spony aj spony typu Riha 5.9 sú najviac zastúpené v západných provinciách (Ettlinger 1973, 100; Philippe 2000, 57). Pre ich tvarovú variabilitu sú datované iba rámcovo do prvého storočia. Optimum ich používania bolo podla sprievodného materiálu v Augste datované do klaudiovsko-fláviovského obdobia (Riha 1979, 134; 1994, 118).

Nová spona zo zbierok RMM z Charvatské Nové Vsi, „Veliké za kovárnou“ (Obr. 3: 15 ; Obr. 6: 4) nemá presne GPS koordináty. Presné miesto nálezu a jeho vztah ku krátkodobému táboru na danom mieste (Vlach 2008, 461) nie je možné určit. Spona nesie stopy pozinkovania. Zachovala sa iba čast’ klenutého lúčika a hlavica spolu s ihlou. Lúčik je delený stredovým plastickým rebrom. Jej blízkymi analógiami sú spony z lokalít na strednej Morave (Zeman 2017a, obr. 10: 4, 8-9). Spona je datovaná do fází stupňa B1c až B2a (Riha 1979, 134).

\subsubsection{Emailové spony typu Exner I 32}

Pre tento typ spony je typický trojuholníkový tvar oblúkového lúčika a zachycovača, ktorý je vyplnený emailovou výzdobou v podobe menších trojuholníkov (Elschek 2017, 169). Ich konštrukcia vychádza zo šarnierových spôn typu Aucissa (Riha 1994, 155).

Pôvod týchto spôn sa, podobne, ako pri iných emailových sponách, kladie do západných provincií (Andrzejowski-Mistewicz-Prochowicz 2009, 670; Boelicke 2002, 114-115; Ettlinger 1973, 107).

Najstaršie nálezové okolnosti kladú počiatky týchto spôn už do klaudiovsko-nerónskeho obdobia (Riha 1994, 139). Tieto spony datujeme 
$\mathrm{v}$ provinciách do tretej tretiny prvého a do počiatku druhého storočia (Böhme 1972, 17). V barbariku sa s emailovými sponami stretávame počas celého druhého storočia a patria medzi oblúbené typy spôn, o čom svedčia početné nálezy z Pol'ska, Česka i Slovenska (Lamiová-Schmiedlová 2003, 46; Andrzejowski-Mistewicz-Prochowicz 2009, 684; Frýzl 2016, 52; Elschek 2017, 169).

Jedna emailová spona bola nájdená na katastri obci Podivín, polohy „Vrt“ (Obr. 6: 2). Ide o emailovú šarnierovú sponu typu Exner I 32. Jej lúčik aj zachycovač majú trojuholníkový tvar vykladaný menšími trojuholníkmi modrého, a na zachycovači aj červeného emailu. Spona je dlhá $1,8 \mathrm{~cm}$, šírka lúčika je $\mathrm{v}$ najširšom bode 0,9 cm. Lúčik je pyramídovo zdobený modrými trojuholníkmi modrého emailu. Na zachycovači sa okrem modrého emailu zachoval aj červený. Sponu možno rámcovo datovat od polovice prvého storočia, do druhej polovice druhého storočia, tj. od fázy B1c až do fázy B2b (Frýzl 2016, 53; Elschek 2017, 171).

\subsubsection{Západné spony s vidlicovitým lúčikom Jobst $16 \mathrm{C}$}

Ide o spony s vidlicovitým lúčikom deleným stredovým výrezom. Boli rozšírené v Panónii a Noriku, ale aj v Británii a Porýní na miestach kastelov a vojenských táborov (Böhme 1972, 26; Jobst 1975, 75; Peškař 1972, 102; Zeman 2017a, 87). Datované sú od konca druhého storočia, naprieč storočím tretím (Böhme 1972, 26; Jobst 1975, 75). V našom súbore sme evidovali 4 nové spony Jobst 16C. Prvá spona je z lokality Kostice, „Kostická váha“ (Obr. 6: 3). Ďalej sú to spony z Rakvic, „Kačenárna - Jezera“ (Obr. 3: 16-18). Ich blízkymi analógiami sú spony z Hronzové Lhoty II a Ostrožské Nové Vsi IV (Zeman 2017a, obr. 18: 25-26). Ďalej je to spona z Carnunta (Peškař 1972, 102, Taf. 18: 8).

\subsection{Doštičkovité spony}

\subsubsection{Spony 7. skupiny podl'a E. Rihovej}

Táto typologicky široká skupina spôn s 27 podskupinami je označovaná ako „Backenscharnierfibeln“ (Riha 1979, 178). Ich charakteristickým znakom je ozdobná doštička rôznych tvarov a výzdoby, na ktorej je zospodu pripevnený šarnierový alebo špirálový mechanizmus (Riha 1979, 178; Bazovský 2005, 48). Za miesto ich vzniku sa tradične označujú provincie v Porýní a v Gálií (Riha 1979, 179).

Prvé nálezy sú datované do klaudiovského obdobia (Riha 1994, 151-152; Feugère 1985, 344, 364, 371). Ich obluba rastie začiatkom druhého storočia a počas neho (Feugère 1985, 371), objavujú sa však ešte v druhej polovici tretieho storočia a na jeho konci (Riha 1979, 186; Feugère 1985, 394).

Z mesta Břeclav, polohy "Přední čtvrtky“ pochádza doštičkovitá spona typu Riha 7.11.4 (Obr. 3:12; Schmid 2010, 54, Abb. 6). Ide o spo$\mathrm{nu}$ kosoštvorcovou doštičkou s dížkou $3,5 \mathrm{~cm}$ a šírkou 2,5 cm. Stredové pole je vyplnené malými výčnelkami, pravdepodobne pre email, ktorý sa nezachoval. Tento typ spôn sa vyskytuje hojne $\mathrm{v}$ podunajskom priestore, na rozdiel od porýnskych provincií (Schmid 2010, 55, Karte 3). Spone z Břeclavi sú analogická spona z Brna (Peškař 1972, 173, Tf. 19: 4), spona zo Zohora (Elschek 2017, 173, obr. 5: 7) a spony z Ostrožské nové Vsy II a Uherského Ostrohu (Zeman 2017a, 92, obr. 19: 16-17). Datovanie danej spony spadá do obdobia tretej tretiny prvého storočia do konca druhej tretiny druhého storočia, tj. do stupňov B1c až B2b s možným presahom (Elschek 2017, 173; Zeman 2017a, 90; Schmid 2010, 173).

Z Lanžhotu, „Hvězda“ pochádza druhá doštičkovitá spona typu Riha 7.2/ Feugère 24a (Obr. 3:13, Riha 1979, 180; Feugère 1985, 184). Ide o kruhovú doštičkovitú sponu o priemere $3,3 \mathrm{~cm}$ so štyrmi polkruhovými výčnelkami le- 
žiacimi krížom oproti sebe. Pre horší stav zachovania sa nedá určit jej prípadne zdobenie. Časté sú hlavne v Gálií, Británii a na Rýne (Feugère 1985, 184). Tieto spony sú datované od Klaudiovského naprieč Fláviovským obdobím do konca prvého storočia (Riha 1979, 180; Boelicke 2002, 120; Gáspár 2007, 43). Danú sponu sme teda datovali do fázy B1c. Spona z Lanžhota zostáva problematickou pre perforáciu pre špirálu a háčik na uchytenie tetivy, čo je charakteristické skôr pre germánske spony. Jej pôvod teda nie je istý.

\subsubsection{Tzv. zvieracie spony}

Tieto spony majú svoje pomenovanie podla doštičky tvarovanej do podoby rôznych druhov zvierat ako labut', hus, holub, jeleň či kôň. Pre spony prvého a druhého storočia je príznačné, že sú skôr ploché a často zdobené emailom. $\mathrm{V}$ tretom a štvrtom storočí sú zdobené napríklad puncovaním a gravírovaním (Kubín 2002, 65; Frýzl 2016, 58).

Ich pôvod sa kladie do Porýnia a Gálie (Boelicke 2002, 128; Riha 1994, 78; Ortisi-Pröttel 2002, 44). V barbariku sú zvieracie spony pomerne vzácne (Kubin 2002, 65; Frýzl 2016, 58). Zo strednej Moravy publikoval niekol'ko zvieracích spôn vo svojej práci T. Zeman (2017a, 93-94). Z Čiech evidoval J. Frýzl k roku 2016 šesṫ zvieracích spôn, ktorých proveniencia nie je vždy jasná (Frýzl 2016, tab. 1; Pecinouská 2008, 39-40).

Počiatok zvieracích spôn sa kládol do klaudiovsko-nerónskeho obdobia (Boelicke 2002, 128). Niektoré nálezy v Lauriacu datoval W. Jobst až do tretieho a následne štvrtého storočia (Jobst 1975, 113). Stratifikované nálezy kládla E. Riha $(1994,78)$ do polovice, prípadne druhej tretiny tretieho storočia.

Do kategórie tzv. zvieracích spôn sme zaradili sponu typu Riha 7.25 / Feugère 29b1 (Riha 1979, 201; Feugère 1985, 389) z lokality
Mušov - Na pískách (Obr. 6: 5). Ide o dvojdielnu sponu, ktorá nie je úplne plochá a nesie na sebe plastické vyobrazenie jazdca a jazdeckého postroja. Pôvod týchto spôn sa kladie do Porýnia a Gálie, o čom svedčia nálezy z Titelbergu, Augstu a d’alších lokalít (Gáspár 2007, Taf. 96: 2168; Riha 1979, Tf. 67: 1730; Riha 1994, Tf. 45: 2905-2906; Rodge 2005, 150-155). V Panónii sa vyskytli pomerne zriedkavo, dve spony poznáme z Carnunta (Matouschek-Nowak 1982, 180, Tf. 12: 41), dve z Viedne, jednu z Pettau a jednu zo Sisaku (Rodge 2005, 119, Fig. 3: 4-7, Fig. 5: 1-4; Patek 1942, Tf. XIX: 17; Koščević 1980, T. XXX: 299). U. Boelicke datuje tieto spony už do klaudiovsko-nerónskeho obdobia (Boelicke 2002, 128), M. Rodge datuje tieto spony do poslednej tretiny prvého storočia s možným vyznievaním do polovice druhého storočia na základe nálezov z Porýnia (Rodge 2005, 161-162).

Ďalšou sponou je tzv. vtáčia spona z Lanžhotu, „Hvězdy“ (Obr. 3: 14). Ide o sponu typu Winter III/ Riha 7.22 (Schmid 2010, 58; Riha 1979, 198). Spona zobrazuje vtáka, pravdepodobne holuba. Pod hlavičkou je úzky vysoký zachycovač. Funkčná čast’ s vinutím a ihlou sa nezachovala. Na založených krídlach je pozorovatel'ná cikcakovitá výzdoba. Jej najbližšími analógiami sú dve spony z canabae z Viedne a spona z Čataja (Schmid 2010, 173, Taf. 39: 314-315; Bazouský 2005, Tab. XVII: 7). Podobné zvieracie spony bez výzdoby datovala E. Riha do prvého storočia (Riha 1979, 85). E. Ettlinger radila takéto plastické vtáčie spony do polovice prvého storočia (Ettlinger 1973, 124). Spony z Viruna boli datované podla nálezových okolností do druhej polovice druhého storočia (Gugl 1995, 47). Sponu možno datovat do stupňa B2b.

\subsection{Výrazne členené spony}

Výrazne členené spony predstavujú výraznú skupinu provinciálnych spôn staršej doby rímskej. Vznikli v norickom juhoalpskom priestore 
niekedy po roku 15 pr. n. 1. zo spôn s prehnutým lúčikom typu A18a (Demetz 1999, 195). Predtým sa usudzovalo, že vznikli z neskoro laténskych typov A 65 (Almgren 1923, 4). Vyrábali sa v podunajských provinciách Panónie a Norikum (Patek 1942, 91-97; Schmid 2010, 144). Rozšírené boli aj v barbariku na juhozápadnom Slovensku (Bazovský 2005, 20-26), v oblasti Púchovskej kultúry (Pieta 2019, 241-284), na južnej a strednej Morave (Kubin 2002, 27-29; Zeman 2017a, 67-76), čiastočne v Čechách a taktiež v Pol'sku (Droberjar 2016, 828-829; Maczyńska 2001, 165179). Teóriu o možnej výrobe spôn typu A 67 v barbariku podporujú nálezy derivátov týchto spôn na podkarpatskej ukrajinskej lokalite Malá Kopanja (Kolniková-Kolnik 2004, 28, obr. 13). Medzi najnovšími príspevkami v bádaní o týchto sponách je súbor výrazne členených spôn nájdených na sídlisku v Mikulove, spracovanom V. Kornhäuserovou (2020, 20, 100, Graf. 3). $\mathrm{V}$ počte 57 kusov predstavujú najpočetnejšiu skupinu spôn na danej lokalite vôbec (Kornhäuserová 2020, 21, Mapa 6, 100, Graf. 3).

$\mathrm{V}$ nami skúmanom súbore sme vybrali 29 spôn. Z týchto spôn 2 nebolo možné klasifikovat pre ich zlý stav zachovania. V prípade, že sa zachová iba hlavica, je problematické či dokonca nemožné určit presný typ, nakol'ko pri tejto skupine spôn je dôležitým determinantom lúčik (Zeman 2017b, 292).

\subsubsection{Spony typu Almgren 67}

Spony typu A 67 sú prvé zo série výrazne členených spôn. Charakteristické sú jednodielnou konštrukciou, lúčikom s jedným uzlíkom, hlavicou rozširujúcou sa smerom od lúčika, natiahnutým prelamovaným zachycovačom s obdľžnikovými či štvorcovými otvormi, a pätkou ukončenou gombíkom. Vznikli niekedy po roku 15 pred. n. 1. zo spôn s prehnutým lúčikom typu A18a, pravdepodobne v juhoalpskom prostredí, kde boli aj dalej rozšírené (Jobst 1975, 30; Demetz 1999, 195).
V barbariku sú známe hlavne na pohrebiskách v Dobřichově-Pičhoře a Třebusicích (Droberjar 2016, 828-829). Pomerne hojne sa vyskytovali aj na území púchovskej kultúry (Pieta 2019, 241-284). Menej exemplárov bolo známych z Moravy (Peškaŕ 1972, 77; Zeman 2017a, 68). V Čechách sú tieto spony datované do fáz B1a-B1b (Droberjar 1999, 141). Tieto spony korelujú s historickými správami o presune mocenského centra z Čiech na juhozápadné Slovensko po páde tzv. Marobudovej ríše. Zatial čo typ A67a je typický pre Čechy, typ A67b sa vyskytuje už aj na území juhozápadného Slovenska (Droberjar 2007, 49; Kolniková-Kolnik 2004, 27). Nosené bolo minimálne do štyridsiatych rokov prvého storočia, najčastejšie v neskoroaugustovskom až tibériovsko-klaudiovskom období (Riha 1979, 73; Demetz 1999, 135).

Z predkladaných nálezov by sme mohli k typu A 67 hypoteticky priradit hlavicu spony z Ladné, „Kerchovka/Kerchovská“ (Obr. 2: 4, Obr. 5: 4). Hlavici sa nezachovalo vinutie, je masívna s široko vytiahnutou záhlavnou doštičkou. Spodná hrana hlavice je výrazne profilovaná. Jej stav zachovania však nedovoluje vylúčit, že ide o iný typ výrazne profilovanej spony.

\subsubsection{Spony typu Almgren 68}

Rozdielom oproti typu typu A 67, je v prípade spôn typu A 68 lúčik, perforovaný troma, či dvoma kruhovými otvormi. Staršie a väčšie spony majú otvory tri, zatial' čo mladšie sú esovito prehnuté a otvory majú dva (Gugl 1995, 12; Bazovský 2005, 22). Sú logickým vývojovým štádiom a pravdepodobne boli vyrábané na rovnakých miestach (Zeman 2017b, 191-292).

Výrobu máme doloženú napríklad na Magdalensbergu či vo Virune (Sedlmayer 2009, 33, Taf. 23: 478, 480; Gugl 1995, Taf. 3). V naddunajskom barbariku sú jedným z najčastejším druhov spôn staršej doby rímskej. Vypovedajú o tom početné nálezy z Moravy (Tejral 1970; Ze- 


\begin{tabular}{|l|c|l|}
\hline \multicolumn{1}{|c|}{ Typ spony } & Počet & \multicolumn{1}{c|}{ Lokality } \\
\hline A67 & 1 & Ladná "Kerchovka/Kerchovská" \\
\hline A68 & 1 & Lanžhot "Podsedky" \\
\hline A69 & 3 & Dolní Bojanovice, Ladná, Nové Mlýny \\
\hline A68-69 & 4 & Ladná (2), Lanžhot (1), Milovice (1) \\
\hline A70/73 & 4 & Lanžhot, Milovice \\
\hline A84 & 11 & Hrušky, Lanžhot, Ladná, Mikulov, Rakvice \\
\hline A85 & 3 & Lanžhot, Milovice, Pohořelice \\
\hline Jobst 4F & 2 & Lanžhot "Kazubek", "Hvězda" \\
\hline Neurčené & 2 & Hrušky, Př́tluky \\
\hline
\end{tabular}

Tab. 2: Výrazne členené spony skúmané v článku.

Chart 2: Strongly profiled brooches mentioned in article.

man 2017a, 68-70), Čiech (Droberjar 2016, 829), juhozápadného Slovenska (Bazovský 2005, 22) ale aj Polska, kde sa vyskytujú ako bronzové, tak miestne železné varianty (Maczyńska 2001, 179, Abb. 2). Prvýkrát sa spony typu A 68 objavujú už v tibériovskom období (Sedlmayer 2009, 33). Obdobie ich používania sa v Magdalensbergu udavá do klaudiovského obdobia, v ktorom osídlenie končí. Mladšie spony s dvoma kruhovými otvormi sú datované do post fláviovského obdobia tedy na koniec fázy B1c (Bazouský 2005, 23; Schmid 2010, 21). Krátke formy bez perforácií vyznievajú do fázy B2a (Bazovský 2005, 22-23).

Za exemplár typu A 68 môžeme označit s určitostou jednu sponu z Lanžhota, polohy „Podsedky“ (Obr. 1: 3). Spona má nalomený zachycovač, avšak v jeho zachovanej časti je kruhový otvor, indikujúci, že môže ísṫ o typ A 68, spona je masívnejšia než spony typu A 68/69. Medzi typ A 68 by mohla byt zaradená aj spona z Milovic, „Bulharska“ (Obr. 2: 2; Obr. 5: 2). Môžeme ich datovat' do druhej polovice prvého storočia, tj. fázy B1c.

\subsubsection{Spony typu Almgren 69}

Spony typu A 69 sú pokračovaním vo vývoji výrazne členených spôn. Ich zachycovač je na rozdiel od spôn typu A 67 a A 68 plný, nie prelamovaný či perforovaný, lúčik menej prehnutý a hlavica často facetovaná (Sedlmayer 1995, 17; Zeman 2017b, 295). Vyskytovali sa jednodielne a neskôr aj dvojdielne spony.

Stretávame sa s nimi hlavne v Panónii a Noriku (Gugl 1995, Beil. 1; Sedlmayer 1995, 13; Schmid 2010, 21-22). Hojný počet nálezov je aj v barbariku (napr. Peškař 1972, 79; Droberjar 2016, 830; Zeman 2017b, 295). Spony typu Almgren 69 sú chronologicky radené do druhej polovice prvého storočia, respektíve až na jej koniec podla nálezov v Podunajsku a na počiatok storočia druhého (Jobst 1975, 33; Schmid 2010, 22; Zeman 2017b, 295).

S istotou môžeme za spony typu A 69 označit spony z obce Dolní Bojanovice „Nivky u starého rybníka“ (Obr. 1: 4) a Ladná „Kerchovka/Kerchovská“ (Obr. 2: 1, Obr. 5: 1). Spona z Dolních Bojanovic je zároveň jediná výrazne členená 
spona, ktorá sa zachovala celá. Spone z Ladné chýba vinutie a ihla. Ďalšie spony môžeme pre chýbajúci či poškodený zachycovač označit ako typ A 68/69. Ide o spony z lokalít: Ladná „Orané louky“ (Obr. 1: 7), Milovice „Bulharsko“ (Obr. 2: 2, Obr. 5: 2), Lanžhot „Hvězda“ (Obr. 1: 13), Př́itluky „Veliký hon“ (Obr. 2: 3, Obr. 5: 3). Tieto spony môžeme datovat do fázy B1c, prípadne počiatok fázy B2a.

\subsubsection{Spony typu Almgren 70/73}

Tieto spony môžu byt’ ako jednodielne, tak dvojdielne (Riha 1979, 74). Pre spony typu A 70/73 je charakteristické zahnutie hlavice smerom k spodnej strane zachycovača. Spony nemajú esovito prehnutý lúčik a zachycovač má vysoký obdĺžnikový až štvorcový tvar (Gugl 1995, 13-19).

Hlavnou oblastou výskytu bolo Norikum (Zeman 2017a, 70). Na Magdalensbergu ich nachádzame až v osídlení z druhého storočia (Sedlmayer 2009, 34). V barbariku nepatria medzi časté druhy spôn (Kubín 2002, 129-135; Bazovský 2005, 23). Nasledujúc spony typu A 69, sa spony typu A 70/73 vyrábali od poslednej tretiny prvého storočia, s dobou výskytu do polovice druhého storočia, objavujú sa však vzácne i na počiatku tretieho storočia ( Gugl 1995, 13-19; Kubin 2002, 33; Schmid 2010, 24).

Z Milovic, „Bulharska“ pochádza jedna hlavica dvojdielnej spony A 70/73 (Obr. 5: 5). Z rovnakej obce, polohy „Spitzhübel“ evidujeme jednu nôžku spony spolu so zachycovačom (Obr. 2: 10, Obr. 5: 11). Ďalšia spona z Lanžhota bohužial' nemá presné zameranie, ani určenú polohu (Obr. 2: 11, Obr. 5: 12). Ich blízkymi analógiami sú spony na strednej Morave (Zeman 2017a, 71, obr. 12). Rámcovo môžeme tieto spony datovat do stupňa B2 (Kubin 2002, 33; Schmid 2010, 23-24).

\subsubsection{Spony typu Almgren 84}

Ide o spony dvojdielnej konštrukcie odlišujúce sa od typov A 67-73 chýbajúcou opornou doštičkou, sploštenou strechovou hlavicou a úzkym vyšším zachycovačom a strechovito hraneným lúčikom (Kubin 2002, 36). Ide o jednu z najrozšírenejších foriem spôn $\mathrm{v}$ podunajskom priestore vôbec (Kubín 2002, 34; Zeman 2017a, 72).

Miestom vzniku týchto spôn boli pravdepodobne Norikum a severozápadná Panónia ( $\mathrm{Pa}$ tek 1942, 21-27; Jobst 1975, 40; Sedlmayer 1995, 29). Pomerne vysoký počet nálezov bol registrovaný z Dácie Superior, len k roku 2004 to bolo 173 kusov (Cocis 2004, 66). Podobne ako iné výrazne členené spony, ani tieto spony nepatria v západných provinciách medzi rozšírené typy (Riha 1979, 80). Hojne sa vyskytujú aj v oblasti juhozápadného Slovenska, naddunajskej časti Rakúska, na Morave, v Čechách a Pol’sku (Peškař 1972, 80-81; Dabrowska 1994; Bazouský 2005, 23-24; Zeman 2017a, 72). Väčšina nálezov je datovaná do druhej polovice druhého storočia, do mladšej fázy $\mathrm{B} 2 \mathrm{~b}$ predchádzajúce prechodnému stupňu markomanských vojen B2/C1 a počas neho (Jobst 1975, 41; Dabrowska 1994, 34; Kubin 2002, 38).

Zo zbierok RMM registrujeme 11 spôn typu A 84. Najlepšie zachovanými kusmi sú spona z Kostic (Obr. 1: 1) a Lanžhota (Obr. 1: 10). Ďalšej spone z Lanžhota chýba vinutia a ihla, telo spony je však kompletné (Obr. 1: 9). V prípade jednej spony z obce Ladná (Obr. 1: 2) a Mikulov (Obr. 1: 6) sa zachovala čast’ lúčiku s uzlíkom a hlavicou s vinutím. V prípade spony z lokality Hrušky „Hrubé Díly“ sa zachovala nôžka so zachycovačom (Obr. 2: 12, Obr. 5: 13). V štyroch prípadoch sa zachovala iba strechovitá hlavica s vinutím, ktorá sa dá priradit k typu A 84. 


\subsubsection{Spony typu Jobst 4F}

Spony typu Jobst 4F patria medzi výrazne členené provinciálne spony. Charakteristické sú lichobežníkovým, či trapezoidným tvarom nôžky, ktorý je často zdobený vlčími zubami, či očkami. Tieto spony sa tradične odvodzujú od spôn typu A 70/73, s ktorými majú zhodný tvar hlavice (Andrzejowski 1992, 111; Kubin 2002, 36).

Výroba spôn sa predpokladá na území Norika, Panónie a Dácie, rozšírenie daného typu naznačuje, že nemuselo íst̉ iba o vojenské spony, nakolko ich nachádzame ako v limitnom, tak aj v civilnom prostredí vo vnútrozemí (Cociş 2004, 59; Komoróczy-Vlach-Zeliková 2017, 43, 50, obr. 10). Za výrobné centrá sa pokladajú Cluj-Napoca, Carnuntum a napríklad aj talianska Aquileia (Gugl 1995, 87; Cocis 2004, 59). V barbariku sa s nimi stretávame hlavne v tzv. sarmatskej oblasti okolo Tisy (Komoróczy-Vlach-Zeliková 2017, 43, obr. 10), v naddunajskom barbariku (Frýzl 2016, 23; Zeman 2017a, 75) a výnimočne aj severne od Karpát (Andrzejowski 1992, 113). Väčšina stratifikovaných nálezov je datovaná do prvej polovice druhého storočia (Andrzejowski 1992, 113; Cociş 2004, 59; Schmid 2010, 25), avšak môžeme sa s nimi stretnút až ku koncu druhého storočia (Jobst 1975, 36-37; Gugl 1995, 20; Cociss 2004, 59).

Z zbierky RMM evidujeme 2 nové exempláre tohto typu. Prvým je bronzová spona z Lanžhota, polohy „Kazubek“ (Obr. 1: 5). Ide o uzlík a nôžku lichobežníkového tvaru a zachycovač. Na nôžke je charakteristická výzdoba na okraji v podobe tzv. vlčích zubov. Zachycovač má tvar obdížnika. Druhým exemplárom je bronzová spona z Lanžhota, „Hvězdy“ (Obr. 1: 11). Spona je od uzlíka deformovaná esovitým prehnutím. Na okrajoch nôžky je nevýrazne čitatel'ná cikcakovitá výzdoba. Zachycovač je štvorcového tvaru. Spony môžeme datovat' do stupňa B2.

\subsection{Panónske trúbkovité spony}

Ide o dvojdielne formy provinciálnych spôn s charakteristickou trúbkovito rozšírenou hlavicou typu A 85 a A 86. Hlavica nesie relatívne dlhé vinutie a môže byt zdobená (Bazovský 2005, 27-28). Sponám typu A 85 chýba záhlavná doštička, čím sa odôvodňuje ich vznik z germánskych trúbkovitých spôn, zatial’ čo spony typu A 86 majú záhlavnú doštičku, a ich pôvod sa odvodzuje od výrazne členených spôn (Zeman 2017, 72).

Výskyt spôn sa koncentruje na území Norika a Panónie, prípadne Balkánu a Dácie ( $\mathrm{Pa}$ tek 1942, 42-43; Bojović 1983, 42-43; Schmid 2010, 30; Cociş 2004, 114). Za miesto obchodu s týmito sponami sa pre ich vysokú koncentráciu označuje Siscia (Jobst 1975, 42-43; Koščević 1980, 25-26). Panónske trúbkovité spony sú obecne radené do druhého storočia. V datovaní sa všeobecne zhoduje väčšina autorov (Patek 1942, 40-42; Jobst 1975, 42-44; Riha 1979, 81; Schmid 2010, 30). Vel'ká čast̉ nálezov pochádza z povrchových prieskumov (Kubin 2002, 40-42; Schmid 2010, 30). Spony A typu 86 je možné datovat’ od polovice druhého storočia až na prelom tretieho storočia (Zeman 2017a, 75).

Novými exemplármi panónskych trúbkovitých spôn z RMM sú tri spony typu A 85 a to: hlavica spony z Lanžhota „Hvězdy“ (Obr. 1: 14), spona z Milovic „Spitzhübel“ (Obr. 6: 6) a spona z Pohořelic, „Nové louky“ (Obr. 6: 7). Sponám chýba ihla a vinutie. $\mathrm{K}$ týmto sponám poznáme analogické moravské spony známe už I. Peškařovi (1972, Tf. 14: 6-8). Zo strednej Moravy publikoval novšie povrchové nálezy $\mathrm{T}$. Zeman (Zeman 2017a, 72, 75, obr. 15: 1-6). Nami skúmané spony môžeme iba rámcovo datovat do stupňa B2 až B2/C1. 


\subsection{Kolienkovité spony}

Kolienkovité spony sú provinciálne spony so špirálovou dvojdielnou konštrukciou charakteristické záhlavnou doštičkou rôznych tvarov a výrazne prehnutým lúčikom, od ktorého dostali svoje pomenovanie, nem. „Kniefibeln“ (Jobst 1975, 59; Böhme 1972, 18-22). Tieto spony sú rozšírené od Británie a Porýnia až k podunajským provinciám (Jobst 1975, 59; Schmid 2010, 33). Pre ich vysokú koncentráciu v limitnej oblasti boli označované aj ako "Limesfibeln“ (Patek 1942, 131). V barbariku sú časté hlavne v blízkosti limitu a na miestach rímskych oporných bodov (Kubin 2002, 48-50; Bazouský 2005, 58-61; Frýzl 2016, 59-63). Pre panónske spony je charakteristická horná tetiva, zatial’ čo pre spony z Porýnia je typická tetiva spodná (Patek 1942, 290; Böhme 1972, 19; Schmid 2010, 35). Časovo zodpovedajú období od približne polovice druhého storočia do počiatku tretieho storočia (Kubin 2002, 44; Frýzl 2016, 71-72). Typologicky ich delíme na niekol'ko skupín podla tvaru záhlavnej doštičky či spôsobu konštrukcie vinutia. Doštička môže byt polkruhová, štvorcová, či trojuholníková (Böhme 1972, 18-22; Jobst 1975, 59-68).

\subsubsection{Spony typu Jobst $13 \mathrm{C}$}

Kolienkovité spony typu Jobst 13C s nezdobenou záhlavnou doštičkou patria medzi najpočetnejšie spony tejto skupiny. Charakteristické sú polkruhovou nezdobenou záhlavnou doštičkou rôznych vel'kostí. Pätka môže byt’ zrezaná, alebo naopak zakončená gombíkom. Mladšie varianty týchto spôn sú rozmerovo menšie, s malou, niekedy až zakrpatenou záhlavnou doštičkou (Jobst 1975, 243; Droberjar 2012, 123).

Z RMM registrujeme 11 nových spôn Jobst 13C z lokalít: Břeclav „Lány“ (Obr. 3: 4), Lanžhot „Hvězda/ Kostická váha“ (Obr. 3: 7-8, 10-11; Obr. 3: 2, 4), Mušov - Na pískách so spodnou tetivou (Obr. 4: 6) a Podivín „Hruštičky“ (Obr. 3: 5). Tieto spony môžeme datovat' do obdobia druhej polovice druhého storočia, tj. do fázy B2b a prechodného stupňa B2/C1 v období pred a počas markomanských vojen.

\subsubsection{Spony typu Jobst 13D}

Tvarovo tieto spony odpovedajú sponám typu Jobst 13C, s rozdielom, že spony typu Jobst 13D majú záhlavnú doštičku zdobenú cikcakovitými vrypmi, tzv. vlčími zubami, najčastejšie kopírujúcimi okraj doštičky (Zeman 2017a, 80). Spony s výzdobou v podobe troch či viacerých spojených polkruhov pod okrajom doštičky majú mat svoj pôvod v hornogermánsko-raetskej oblasti (Sedlmayer 1995, 43-44), zatial’ čo spony s výzdobou v podobe koncentrických poloblúkov a lúčovitých línií majú mat svoj pôvod v podunajských provinciách (Jobst 1975, 66; Schmid 2010, 35).

Do zbieky RMM pribudlo 6 nových spôn typu Jobst 13D. Ide o spony z lokalít: Ladná „Kerchovka/Kerchovská“ (Obr. 4: 1), Lanžhot „Hvězda- Kostická váha“ so spodnou tetivou (Obr. 4: 3), Mikulov „Na Mikulovsku“ (Obr. 4: 10) a Mušov „Burgstall“ (Obr. 4: 8-9). Ďalšou sponu je hlavica spony z Pasohlávek "Lopoty“ (Obr. 4: 7). Dané spony môžeme datovat do stupňa B2/C1 do začiatku tretieho storočia.

\subsubsection{Spony typu Jobst $13 \mathrm{E}$}

Tieto spony sa od predchádzajúceho typu lísia výzdobou záhlavnej doštičky, ktorú predstavujú vybíjané malé polkruhy do rôznych tvarov. Vo Vindobone našli tieto spony ako na mieste tábora, tak aj v civilnom osídlení (Schmid 2010, 35-36, Kat. Nr. 186-192). Z RMM sme evidovali štyri nové spony typu Jobst 13E. Ide o spony z lokalít: Charvatská Nová Ves, „Veliké za kovárnou“ (Obr. 6: 8), Lanžhot „Hvězda“ (Obr. 


\begin{tabular}{|l|c|l|}
\hline \multicolumn{1}{|c|}{ Typ spony } & Počet & \multicolumn{1}{c|}{ Lokality } \\
\hline Jobst 13 C/D & 1 & Mušov, "Burgstall" \\
\hline Jobst 13C & 11 & Břeclav: 1, Lanžhot: 7, Mušov: 1, Pasohlávky: 1, Podivín: 1 \\
\hline Jobst 13D & 6 & Ladná, Lanžhot: 2, Mikulov, Mušov: 2 \\
\hline Jobst 13E & 4 & Charvatská Nová Ves, Lanžhot/ Kostice: 2, Rakvice \\
\hline Bojović 21.3 & 1 & Lanžhot, "Hvězda" \\
\hline Bojović 22.2 & 1 & Mikulov, "Kamenné" \\
\hline
\end{tabular}

Tab. 3: Kolienkovité spony.

Chart 3: Knee brooches.

3: 1-2), Rakvice „Pod Koziberky“ (Obr. 4: 12). Hlavička spony z Rakvic má spodnú tetivu. Spona z Lanžhota má okrem rytej výzdoby okraja záhlavnej doštičky aj lúčovité línie vedené odstredivo k okraju doštičky ohraničené puncovanými pásmi (Obr. 3:2; Sedlmayer 1995, 43-44). Jej blízkou analógiou je spona zo Strážnic/ Petrova III (Zeman 2017a, 79, obr. 17: 4). Spony Jobst 13E možno datovat' ešte pred stupeň B2/ C1 a počas tretieho storočia, o čom svedčia nálezy z Lauriaca, datované až ku počiatku štvrtého storočia (Jobst 1975, 67; Schmid 2010, 35-36; Zeman 2017, 80a). V tomto prípade je však pravdepodobné, že ide o starožitnosti.

\subsubsection{Spony typu Bojović 21}

Novým prírastkom tohto typu je spona z Lanžhota, "Hvězdy“ (Obr. 3: 6). Ide o sponu typu Bojović 21.3 s obdlžníkovou záhlavnou doštičkou a dvojdielnou funkčnou častou. Lúčik je hranatý, pätka nôžky je zakončená gombíkom a zachycovač je relatívne úzky. V tomto type kolienkovitých spôn vidí D. Bojović (1983, 56) medzistupeň medzi sponami s polkruhovou záhlavnou doštičkou a kolienkovitými sponami so šarnierovou konštrukciou. Tieto spony po- známe z Panónie, Balkánu a taktiež z Dácie (Koščević 1980, 27-28; Bojović 1983, 56; Cocis 2004, 99). Jedna spona typu Bojović 21 sa našla aj v Prahe-Dejvice/ Podbaba (Droberjar 2012, 122). Tieto spony môžeme datovat do druhej polovice druhého storočia s presahom do tretieho storočia, tj. do stupňov B2/C1 a C1 (Bojović 1983, 56; Droberjar 2016, 832).

\subsubsection{Spony typu Bojović 22}

Medzi tieto spony patrí spona z Mikulov, polohy „Na kamenné“ (Obr. 4: 11). Ide o formu kolienkovitých spôn so šarnierovou konštrukciou typu Bojović 22.2. Pri tomto type úplne chýba klasická záhlavná doštička, lúčik je masívny a pätka nôžky je zakončená gombíkom. Takéto spony sú zastúpené ako v Podunajsku, tak hlavne na Balkáne a v Dácií (Patek 1942, 135; Bojović 1983, 58; Haralambieva 1993, 102; Cociş 2004, 97). Blízkymi analógiami sú spona z Prahy-Dejvic/ Šárky (Droberjar 2012, 122). Všeobecne sa tieto spony datujú od prechodného stupňa B2/C1 až do polovice tretieho storočia (Bojović 1983, 57-59; Cocis 2004, 97, 101). 


\section{Chronologická a geografická analýza súboru}

\subsection{Chronologická analýza}

\subsubsection{Stupeň B1}

Do stupňa B1 môžeme priradit’ 14 spôn. Do fáz B1a-B1b by sme mohli hypoteticky klasifikovat jednu hlavicu spony typu A 67 z Ladné „Kerchovky/Kerchovské“ (Obr. 2: 4, Obr. 5: 4), nakol'ko je však zachovaná iba samotná hlavica, nie je možné bezpečne určit o aký variant výrazne členenej spony ide. Ďalej sem patrí spona typu A 68 z Lanžhota „Podsedky“. Medzi fázy B1b/ B1c patrí šarnierová spona typu Riha 5.9 z Charvatské Nové Vsi (Obr. 3: 15 ; Obr. 6: 4). Pri datovaní sa môžeme opriet̉ o nálezy z pohrebiska vo Velaticiach, z ktorých evidujeme hroby so sponami typu A68 datované do fázy B1b (hrob 4, Jilek-Kuča-Sojková 2011, Tab. III: 4) až B1c (hrob 20, Jilek-Kuča-Sojková 2011, Tab. VIII: 2).

\subsubsection{Fáza B1c a Stupeň B2}

Do fázy $\mathrm{B} 1 \mathrm{c}$ radíme výrazne členené spony typu A 68/69 spolu s doštičkovitou sponou typu Riha 7.2. Ďalej do fáz B1c a B2a patrí vojenská spona typu A 15 z Milovic (Obr. 6: 1), doštičkovitú jazdeckú sponu typu Riha 7.25 z Mušova - Na pískách (Obr. 6: 5). Do fázy
B2a môžeme evidovat’ výrazne členené spony typu A 70/73. Tieto spony poznáme z Josefova (Zeman 2017a, 71, Obr. 12: 17), či sídliska v Jevišovke (Zeliková 2019, 83, obr. 33: 1-6), sídliska v Hrušovanoch u Brna (Filipová-Harangozóová 2014, obr. 10: 7) alebo sídliska v Mikulove (Kornhäuserová 2020, 25). Rámcovo do druhého storočia radíme panónske trúbkovité spony typu A85 a A86 (Peškař 1972, Tf. 14: 6-8) spony typu Jobst 4F, prítomné aj na iných moravských lokalitách (ז̌ihovský 1951, 49, obr. 43; Peškař 1972, 36, Tf. 12: 1; Frýzl 2016, 23; Kornhäuserová 2020, 28), emailovú sponu z Podivína (Obr. 6: 2), sponu typu Riha 7.11.4 z Břeclavi (Obr. 3: 12) a zvieraciu sponu typu Riha 7.22 z Lanžhota (Obr. 3: 14). Do fázy B2b môžeme priradit aj spony A 84, ktoré však môžeme zaradit aj do horizontu B2/C1. Prirátajúc spony z prechodného horizontu B2/C1 patrí do druhého storočia 44 spôn, čo je $65 \%$ všetkých nami skúmaných spôn (Tab. 4).

\subsubsection{Prechodný horizont B2/C1}

Spony tohto horizontu predstavujú najpočetnejšiu skupinu v počte 29 kusov. Patria tu neskoré výrazne členené spony typu A 84 (11 kusov) a rôzne formy kolienkovitých spôn typu Jobst 13 c a 13D, ktoré však mohli pretrvávat až do stupňa C1.

\begin{tabular}{|l|c|c|}
\hline \multicolumn{1}{|c|}{ Stupeň } & Počet & \% zastúpenie \\
\hline B1 & 14 & 21 \\
\hline B2 & 14 & 21 \\
\hline B2 / C1 & 29 & 43 \\
\hline C1 & 10 & 15 \\
\hline
\end{tabular}

Tab. 4: Percentuálne zastúpenie spôn v jednotlivých chronologických stupňoch.

Chart 4: Percentage of roman brooches from each chronological period. 


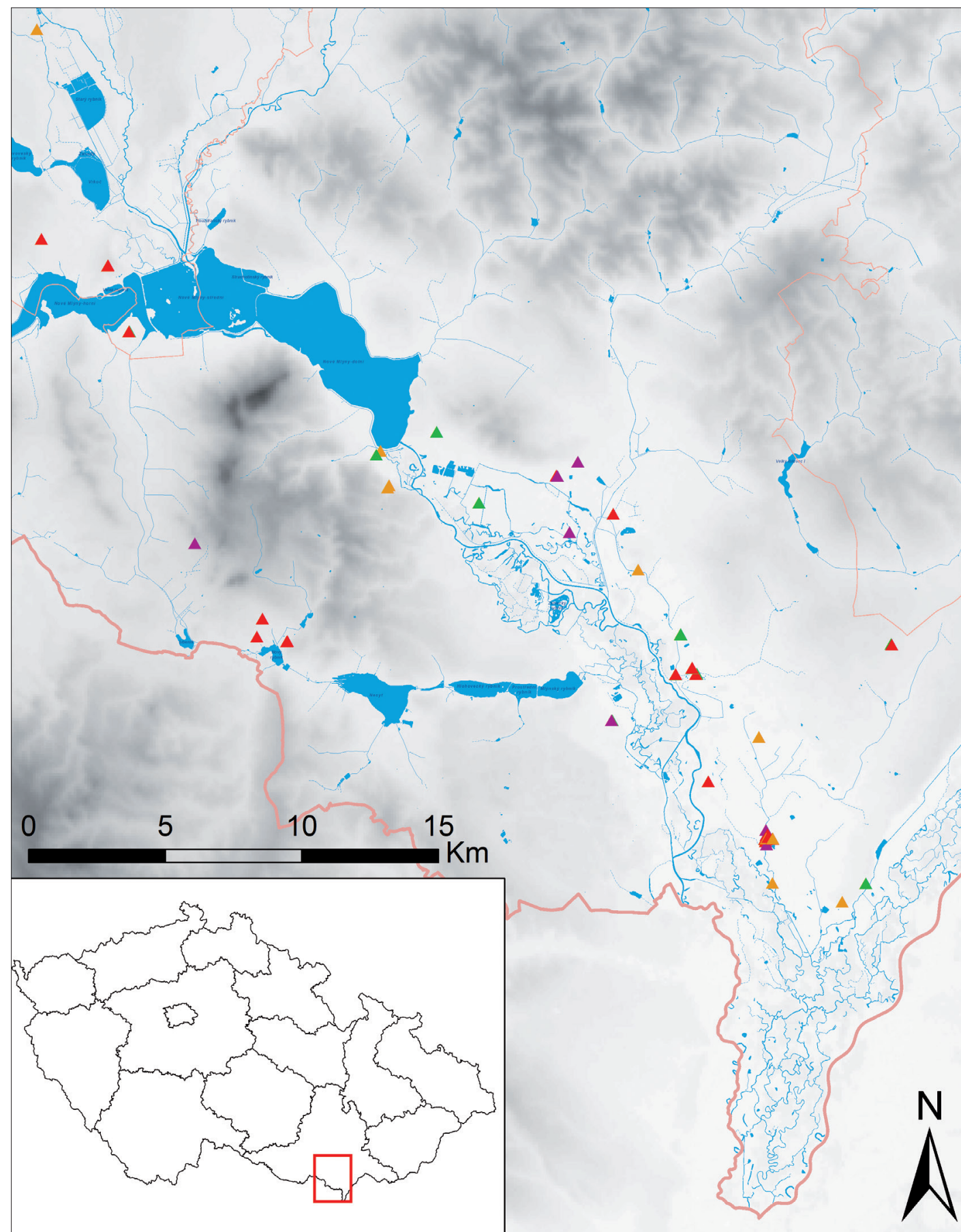

Mapa 2: Geografické rozmiestnenie skúmaných spôn $\vee$ rôznych chronologických stupňoch. $\Delta=B 1, \Delta=B 2$, $\boldsymbol{\Delta}=\mathrm{B} 2 / \mathrm{C} 1, \mathbf{\Delta}=\mathrm{C} 1$.

Map 2: Spatial distribution of roman brooches in different chronological periods. $\mathbf{\Delta}$ - First century $A D, \Delta=1$. half of second century AD, $\boldsymbol{\Delta}=$ Marcomannic wars period, $\boldsymbol{\Delta}=$ third century AD. 


\section{Charvatská Nová Ves}

\begin{tabular}{|l|l|}
\hline \multicolumn{1}{|c|}{ Veliké za kovárnou } & \multicolumn{1}{c|}{ Mušov } \\
\hline Na pískách & Jobst 13C, Jobst 13D, Riha 7.25 \\
\hline Burgstall & Jobst 13, Jobst 13D \\
\hline
\end{tabular}

Tab. 5: Spony z lokalít s prítomnost'ou rímskych táborov.

Chart 5: Roman brooches from vicinity of roman camps.

\subsubsection{Stupeň C1}

Stupeň C1 tvorí posledný časový úsek zachytený medzi skúmanými nálezmi. Zaradujeme sem spony typu Jobst 16C s vidlicovitým lúčikom z obce Rakvice a z Kostic (Obr. 3: 16-18; Obr. 6: 3). Do fázy C1a patria kolienkovité spony typu Jobst 13E z Kostic a Charvatské Nové Vsi a Rakvic (Obr. 6: 8; Obr. 4: 12), spolu so sponami Bojović 21.3 a Bojović 22.2 (Obr. 3: 6, Obr. 4: 11).

\subsection{Priestorové rozloženie nálezov v skúmanom regióne}

Pri pohlade na priestorové rozmiestnenie nálezov môžeme konštatovat', že sa väčšina nálezov koncentruje v tesnej blízkosti rieky Dyje, na jej lavom brehu. Najväčšia koncentrácia nálezov sa nachádza na polohách „Hvězda-Kostická váha“ medzi katastrami obce Lanžhot a Kostice, na katastri obce Ladná „Kerchovka/Kerchovská“, d’alej je to kataster obce Rakvice s piatimi sponami. Ďalšou, tentokrát pravobrežnou lokalitou s kompletne zameranými piatimi sponami sú Milovice. Na lokalitách Ladná „Kerchovka/ Kerchovská“ a Lanžhot „Hvězda-Kostická váha“ sú chronologicky zastúpene spony od polovice prvého storočia až do počiatku storočia tretieho.
3.2.1 Možná súvislost' s dočasnými rímskymi tábormi v Podyjí

Spony z katastra obce Charvatská Nová Ves neboli nálezcami presne zamerané, čo neumožňuje presvedčivo doložit, že nálezy priamo z priestoru krátkodobého tábora (Vlach 2008, 461), alebo z okolia s prípadným germánskym osídlením (Mapa 3). Podobné krátkodobé tábory boli v Podyjí a v blízkosti rieky Moravy nájdené napríklad v Mušove „Na pískách“, v Drnholci, Iváni, Přibicích, či Závode na Slovensku (Komoróczy-Rajtár-Vlach-Hüssen 2020, 173-254). Podobne neboli presne zamerané ani spony z Mušova „Na pískách“ a na hlavnej základni Mušov „Burgstall“ (Komoróczy 2008, 391). Nálezy ale predstavujú typický inventár zhodný s už nájdenými a zdokumentovanými nálezmi z krátkodobých táborov (Peškař 1972, 95-96, Taf. 17-18; Rajtár 2014, Obr. 9, Obr. 11).

Vysoká koncentrácia kolienkovitých spôn a spôn typu A 84, charakteristických pre druhú polovicu druhého storočia na lokalitách „Hvězda-Kostická váha“ a Ladná „Kerchovka/ Kerchovská“ môže súvisiet práve s rímskymi operáciami počas markomanských vojen. Blízkost́ rieky Dyje je určujúca, nakol'ko rieka plnila funkciu dopravnej tepny v smere od rieky Moravy k hlavnému stredisku operácií na polohe Mušov „Burgstall“ (Komoróczy 2008). Ďalšími možnostami sú spolupráca miestnych komunít 


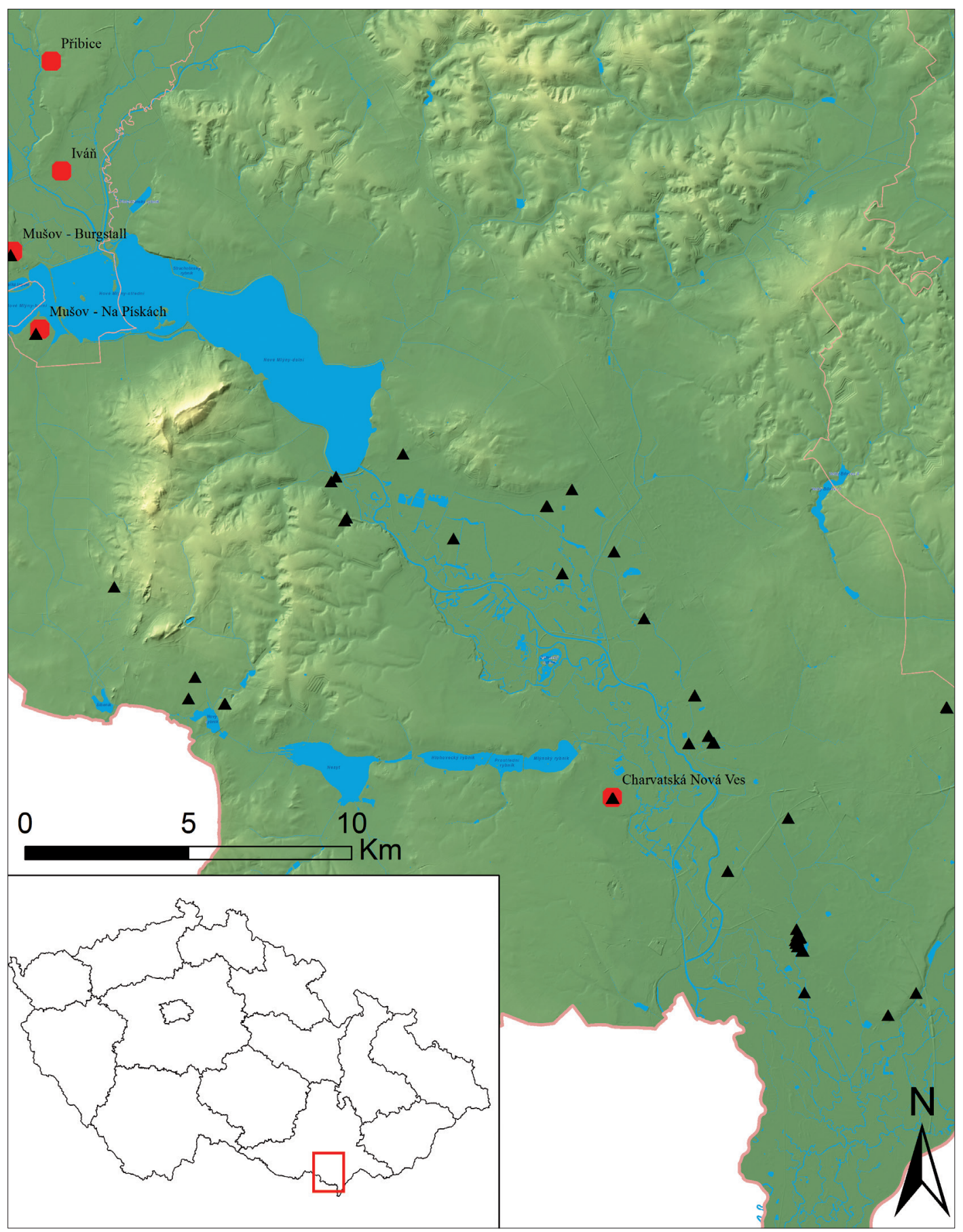

Mapa 3: Rímske vojenské tábory a lokality s nálezmi spôn.

Map 3: Roman temporary camps in relation with finds of roman brooches. 
s Rimanmi (o čom môže svedčit tzv. královský hrob na Mušove), či preberanie kultúrnych vplyvov v rámci módy.

\subsubsection{Porovnanie nálezov s predchádzajúcimi poznatkami}

Nálezy spôn typu A68 a A69 poznáme z kostrových a žiarových hrobov blízkeho pohrebiska v Mikulove, čiastočne odkrytého v 50. rokoch (Řihouský, 1951, 47, obr. 37; Tejral 1970a, 119, obr. 7: 5, 8; Peškař 1972, 32, Tf. 9: 9, Tf. 10: 1, 4-6, 8). Najnovšie detektorové nálezy výrazne členených spôn z blízkeho sídliska v Mikulove publikovala V. Kornhäuserová (2020, 99, Graf 2). Z celkového počtu 142 spôn patrilo medzi výrazne profilované spony 57 kusov, čo je najväčšia podskupina spôn $\mathrm{z}$ danej lokality vôbec (Kornhäuserová 2020, 99, Graf 3, 103, Graf 5). Podobný trend nárastu počtu detektorových nálezov výrazne členených spôn zaznamenali aj na strednej Morave (Zeman 2017a, 65, Graf 5). Výrazne členené spony z povrchových prieskumov tvorili 26,3 \% všetkých spôn, najviac zo všetkých skupín (Zeman 2017a, 67, Graf 6). Z d’alších lokalít v širšom okolí máme doložené rané výrazne profilované spony z Moravského Krumlova (Peškař 1972, Tf. 9: 2, Tf. 10: 7), Dolních Bojanovic (Jilek 2009a, 320, obr. 2:3, 13, 15; Zeman 2017b, 293, obr. 8: 10, 19-21, 24), Uherského Brodu (Peškař 1972, Tf. 9: 8) a Lužice (Zeman 2017b, 293, obr. 8: 23).

Nárast počtu spôn typu A 84 je zjavný ako na strednej Morave, kde tvoril 49,8 \% výrazne členených spôn (Zeman 2017a, 67, Graf 6), tak i na Mikulovsku (Kornhäuserová 2020, 27). Kolienkovité spony sú typickým inventárom nachádzaným na lokalitách s prítomnostou rímskych táborov (Peškař 1972, 95-96, Taf. 17-18; Frýzl 2016, 59-63). Na mieste krátkodobého tábora v Pravčiciach bola nájdená spona typu Jobst 13D (Fojtik-Jilek-Popelka 2015, 187-188, obr. $3)$. Nové výskumy priniesli exempláre kolien- kovitých spôn v spojení so sponami typu Jobst 4F, či A84 z Drnholce, polohy „Holenická pole“ (Komoróczy-Vlach-Zeliková-Sedláček-Růžičková 2019, obr. 19). Okrem rímskych táborov (Komoróczy 2008; Vlach 2008; Kuzmová-Rajtár 2010; Rajtár 2014) poznáme kolienkovité spony z rozrušených hrobov vo Velaticiach (Jilek-Kuča-Sojková 2011, Tab. XVI: 2, Tab. XVII: 4), z hrobu č. 20 v Šitbořicích datovaného do horizontu B2/C1 (Vlach 2010, 109, Tab. 42: 1), z Mikulova (Kornhäuserová 2020, 49), zo sídliska v Hrušovanoch u Brna (Filipová - Harangozóová 2014, obr. 10: 1-2) či Moravského Krumlova (Peškař 1972, Tf. 17: 1-2, 8).

Pri skúmaní spôn sme vychádzali z predchádzajúcich výskumov na vybraných lokalitách, ktoré svojím počtom predstavovali kumuláciu relatívne väčšieho počtu nálezov. Zamerali sme sa na lokality Dolní Bojanovice, Milovice, Rakvice, Ladná a Lanžhot.

Spona typu A 69 z Dolních Bojanovic (Obr. 1: 4) môže súvisiet’ s detektorovými nálezmi germánskych a provinciálnych spôn z rovnakej polohy „Nivky u starého rybníka“ (Jílek 2009a, obr. 2). Medzi nálezmi bola napríklad hlavica spony typu A 68/69 (Jilek 2009a, obr. 2: 3), hlavica spony typu A 70/73 (Jilek 2009a, obr. 2: 15) a nôžka spony typu A 84 (Jilek 2009a, obr. 2: 13). Nález spony z obdobia stahovania národov z roku 2007 napovedá, že môže íst' o prípadné dlho pretrvávajúce sídlisko, nemusí tomu však byṫ tak (Jilek - Jiřrk 2008, 341, Obr. 11).

V katastri obce Milovice uskutočnil I. Peškař povrchové zbery v polohe „U topolů“ SV od obce, pri ktorých našiel črepy keramiky doby rímskej (1971, 20-21). V polohe „Na pískách“ M. Čižmář odkryl neskoro laténske objekty a taktiež uskutočnil zbery, pri ktorých boli nájdene črepy provinciálnej keramiky spolu so zlomkom terry sigillaty $\mathrm{z}$ druhého storočia (Čižmář 1980, 26; Čižmář - Rakouský 1980, 111). Na polohe „Spitzhübel“ uskutočnili pracovníci RMM povrchové zbery, pri ktorých konštatovali 


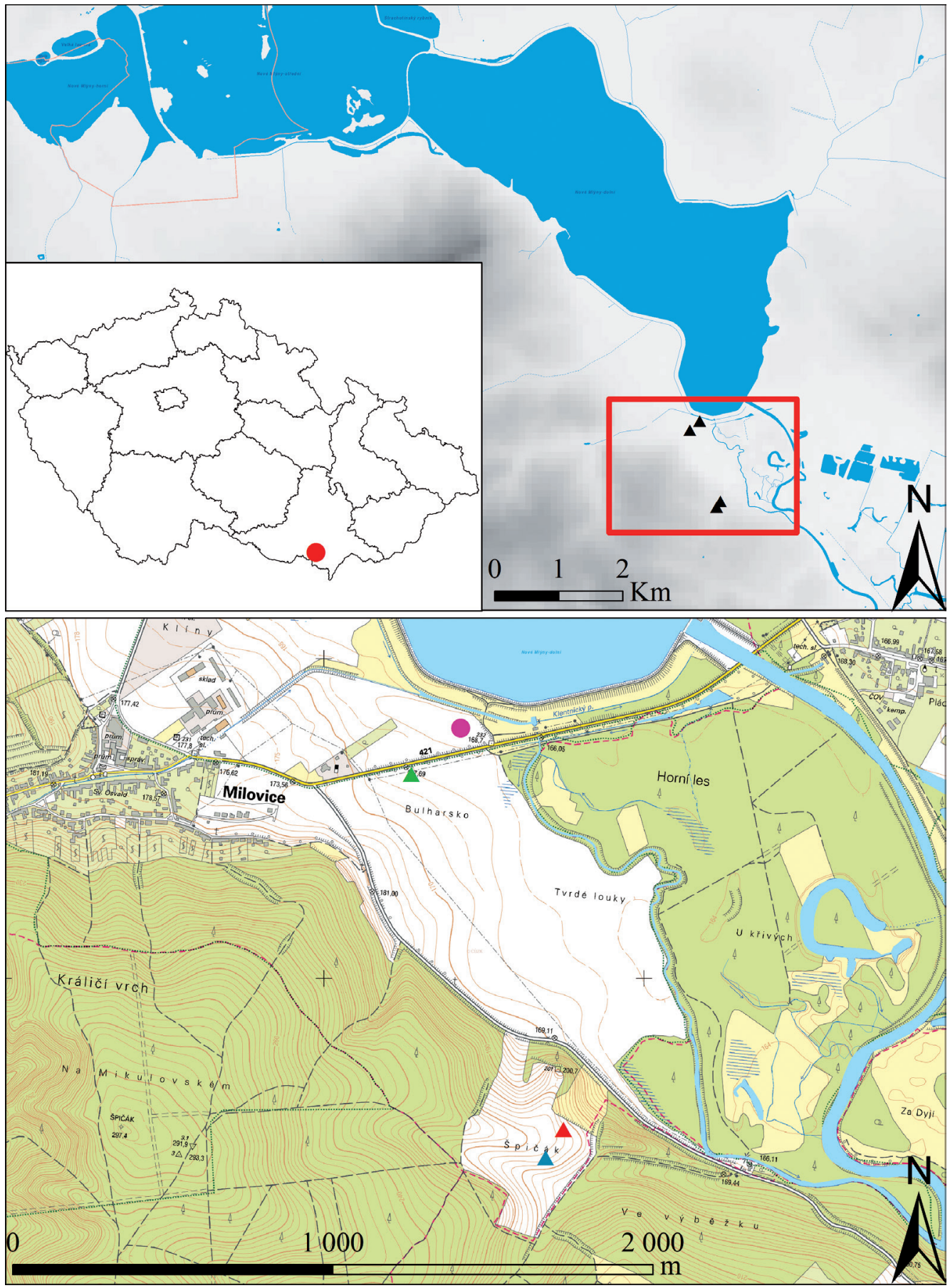

Mapa 4: Nálezy spôn z katastra obce Milovice, okres Břeclav.

Map 4: Finds of brooches from cadastre of Milovice village, Břeclav district. 
vel'kú koncentráciu keramiky doby rímskej a provinciálnej keramiky (Trampota 2016, 249). Zlomky terry sigillaty z druhého storočia korelujú s datovaním výrazne členených spôn typu A 70/73, panónskej trúbkovitej spony a vojenskej spony typu A15 v našom súbore (Mapa 4).

M. Čižmář s kolektívom bádatel'ov získal v katastri obce Rakvice v priebehu rokov 2008 a 2009 časti deviatich spôn a bronzový závesok, datované do doby rímskej spolu s mincou cisára Aureliána, datovanú medzi roky 270 a 275 (Č $i$ žmář et. al. 2009, 145, obr. 7: 1-9). Tento nález z tretieho storočia môže byt' stopou k pochopeniu prítomnosti spôn typu Jobst 16C na katastri obce, ako jediných jasných príkladov spôn z tretieho storočia z nášho súboru. Je nutné však doplnit', že mince obiehali v barbariku podstatne dlhšie.

Obec Ladná bola opakovane navštevovaná archeológmi Archeologického ústavu AV ČR v Brne. V roku 1968 odkryl J. Tejral (Tejral 1970c, 36; Droberjar 1997, 169) na rozhraní katastrov Ladná a Břeclav objekt datovaný do druhej polovice tretieho storočia s provinciálnou keramikou. Rok na to podnikol záchranný výskum (Tejral 1971, 19-20) v priestore miestneho pieskoviska, v ktorom sa mu podarilo odkryt' dva sídliskové objekty s množstvom črepov germánskej i provinciálnej keramiky na poli okolo. V roku 1973 odkryli charakteristický objekt so šiestimi kolovými jamami, datovaný do neskorého druhého storočia (Tejral 1974, 53-54, 186-189). Južne od pieskoviska bol v roku 1975 zrealizovaný väčší odkryv, ktorým bolo odhalených 26 objektov datovaných do neskorého 3. storočia (Tejral 1977, 43-44). Z daného katastrálneho územia pochádza aj rímska bronzová panvica typu Eggers 140/142 z hrobu datovaného do fázy B1c (Tejral 1970a, 102, 105, obr. 8: 1-2; 167; Jilek 2012, 109). Severne od obce bola v roku 2009 nájdená spona s vysokým zachycovačom počas systematickej detektorovej prospekcie (Čižmár̆ et. al. 2010, 134, obr. 7: 3).
Z katastra obce Ladná do zbierky RMM získali celkovo 7 spôn, z toho 4 z polohy „Kerchovka/Kerchovská" s chronologickým rozptylom naprieč prvým a následne druhým storočím (Mapa 5, Mapa 6).

Pri práci so satelitnými snímkami portálov ČUZK a Google Earth sme zachytili pôdne vegetačné príznaky indikujúce prítomnost̉ sídliskových archeologických objektov, ktoré korešpondujú s nálezmi spôn (Mapa 6, Mapa 10). V prípade polohy „Kerchovka/ Kerchovská“ obce Ladná sme na snímkach ČUZK z rokov 2012 a 2016, a snímkach Google z rokov 2009 a 2017 zaregistrovali príznaky obdížnikového či štvorcového tvaru, indikujúce zhluky archeologických objektov (Mapa 6, Mapa 10).

V obci Lanžhot bolo zaznamenané osídlenie doby rímskej výskumom J. Tejrala na trati „Podsedky“ (Tejral 1960, 171; Droberjar 1997, 169). Črepový materiál, ktorý sa k nemu dostal na spracovanie datoval do doby rímskej. Z nálezov vynikalo dno nádoby terry sigillaty, pravdepodobne typu Drag. 37, provinciálna keramika okrovej farby a zlomok prstencovej misky (Tejral 1960, 171). Materiál bol zozbieraný západne od cesty Břeclav-Lanžhot, pravdepodobne z polohy v okolí nami získaných nálezov. Na tom istom mieste bolo odhalených niekol'ko objektov s keramickým obsahom datovaným do doby rímskej (Tejral 1967, 39). Na jar roku 1968 odhalili d’alší objekt na rovnakej polohe s výplňou, obsahujúcou domácu na kruhu točenú jiř́íkovickú keramiku, neskorú provinciálnu keramiku, i keramiku vol'ne vyrábanú v ruke. Objekt bol datovaný do 4. storočia (Tejral 1970b, 36-37). Z publikovaných opisov nie je úplne možné rekonštruovat jednotlivé miesta odkrytých objektov, je však pravdepodobné, že ide o územie či plochu v tesnej blízkosti nálezísk spôn. Z tejto plochy sme registrovali 14 spôn, z ktorých väčšina patrí do druhého storočia (Tab. 7, Mapa 8).

$\mathrm{V}$ prípade polohy „Hvězda-Kostická váha“ (Mapa 8, Mapa 9) sme si povšimli pôdne 


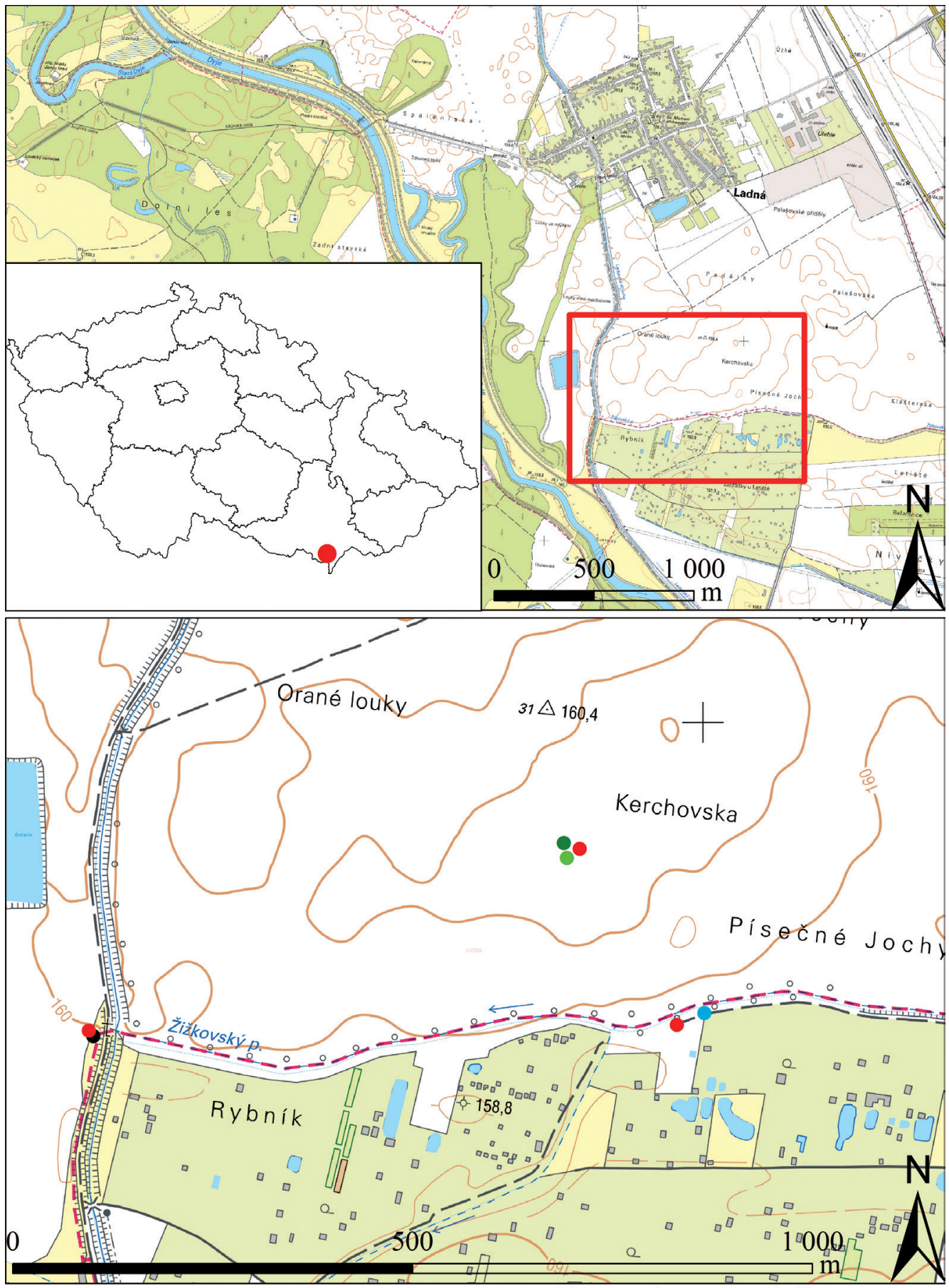

Mapa 5: Ladná, "Kerchovka/Kerchovská" okres Břeclav, lokalizácia zameraných a skúmaných spôn.

Map 5: Ladná, „Kerchovka/Kerchovská” site, Břeclav district. Location of GPS measured finds of roman brooches. 

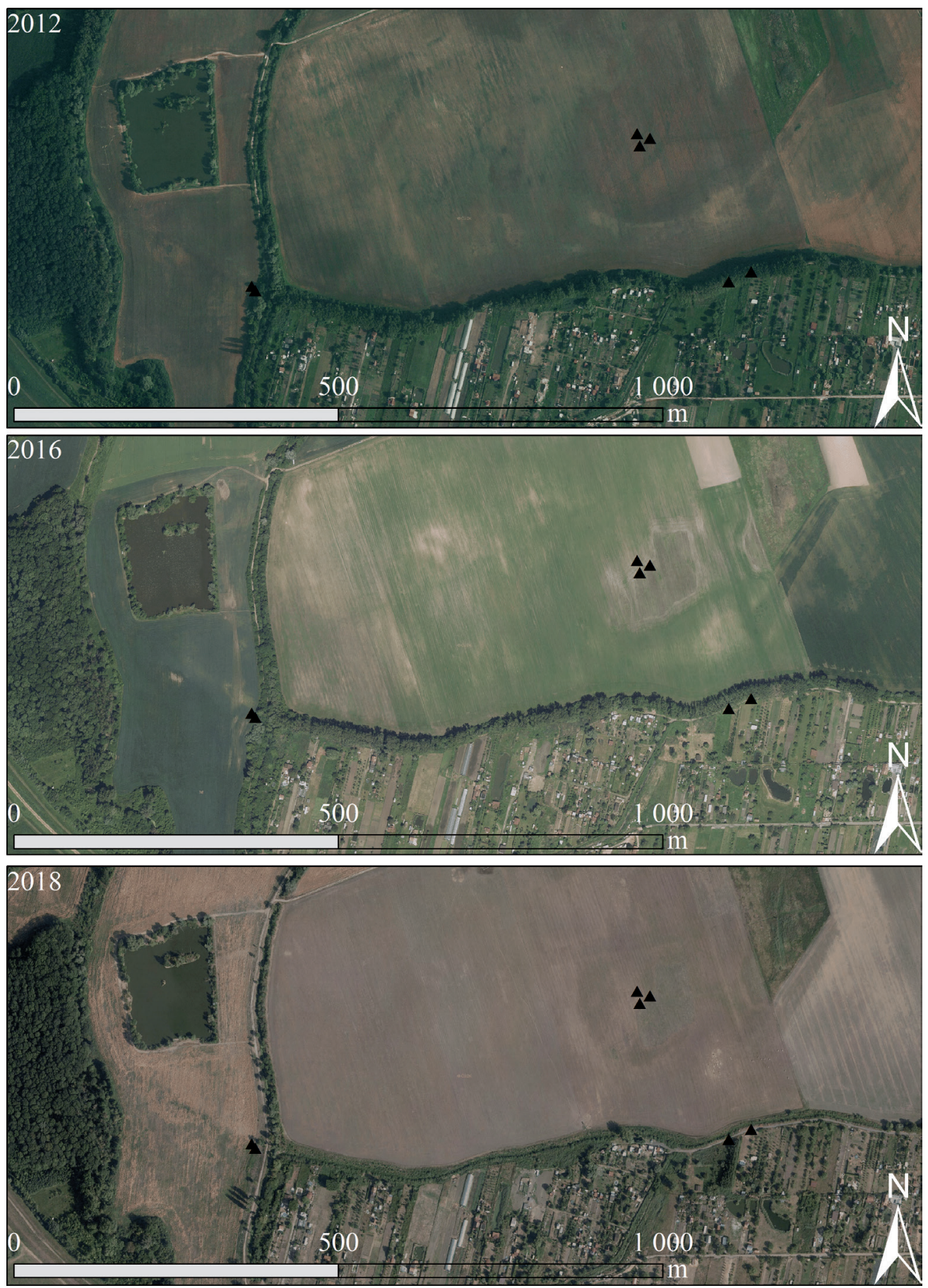

Mapa 6: Ladná, „Kerchovka/Kerchovská” okres Břeclav, satelitné snímky ČUZK.

Map 6: Ladná, „Kerchovka/Kerchovská" site, Břeclav district. Satellite images,

source: State Administration of Land Surveying and cadastre of Czech Republic (ČUZK). 

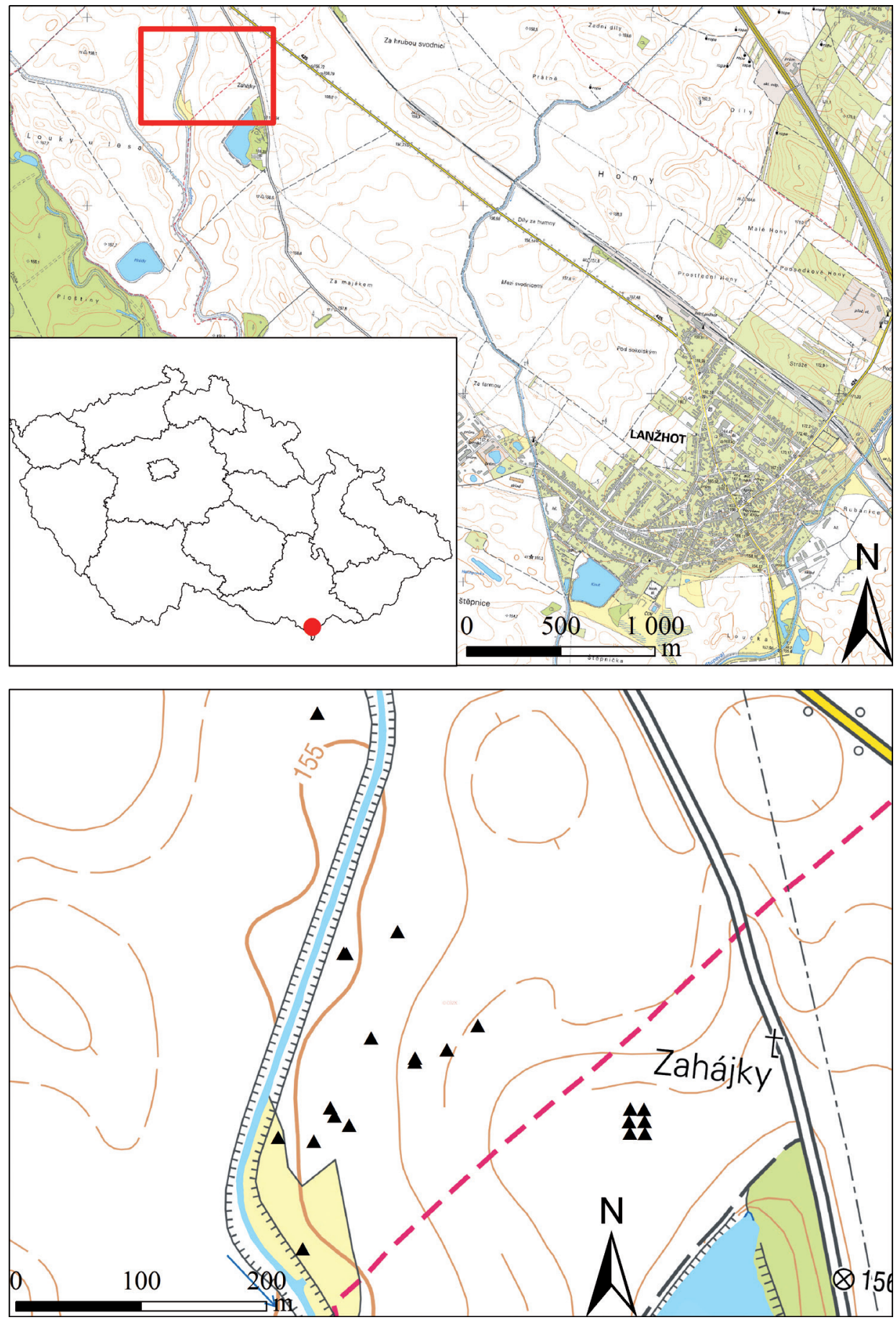

Mapa 7: Kostice / Lanžhot, poloha "Hvězda / Kostická váha," okres Břeclav.

Map 7: Kostice / Lanžhot, "Hvězda/ Kostická váha" site, Břeclav District. 


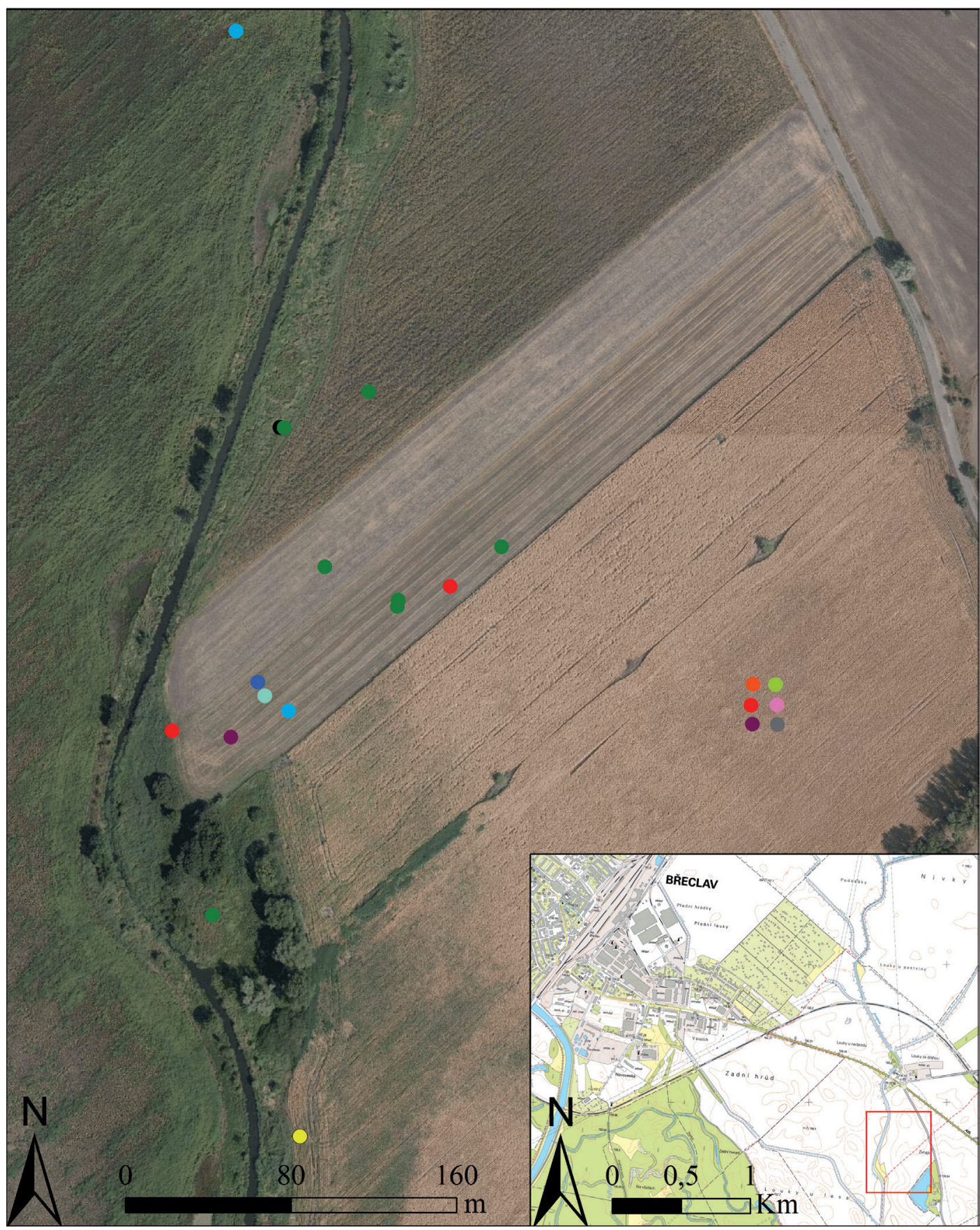

Mapa 8: Kostice / Lanžhot, poloha "Hvězda / Kostická váha," okres Břeclav. Rozmiestnenie rôznych typov rímskych spôn.

Map 8: Kostice / Lanžhot, "Hvězda/ Kostická váha" site, Břeclav District. Spatial distribution of different types of roman brooches. 

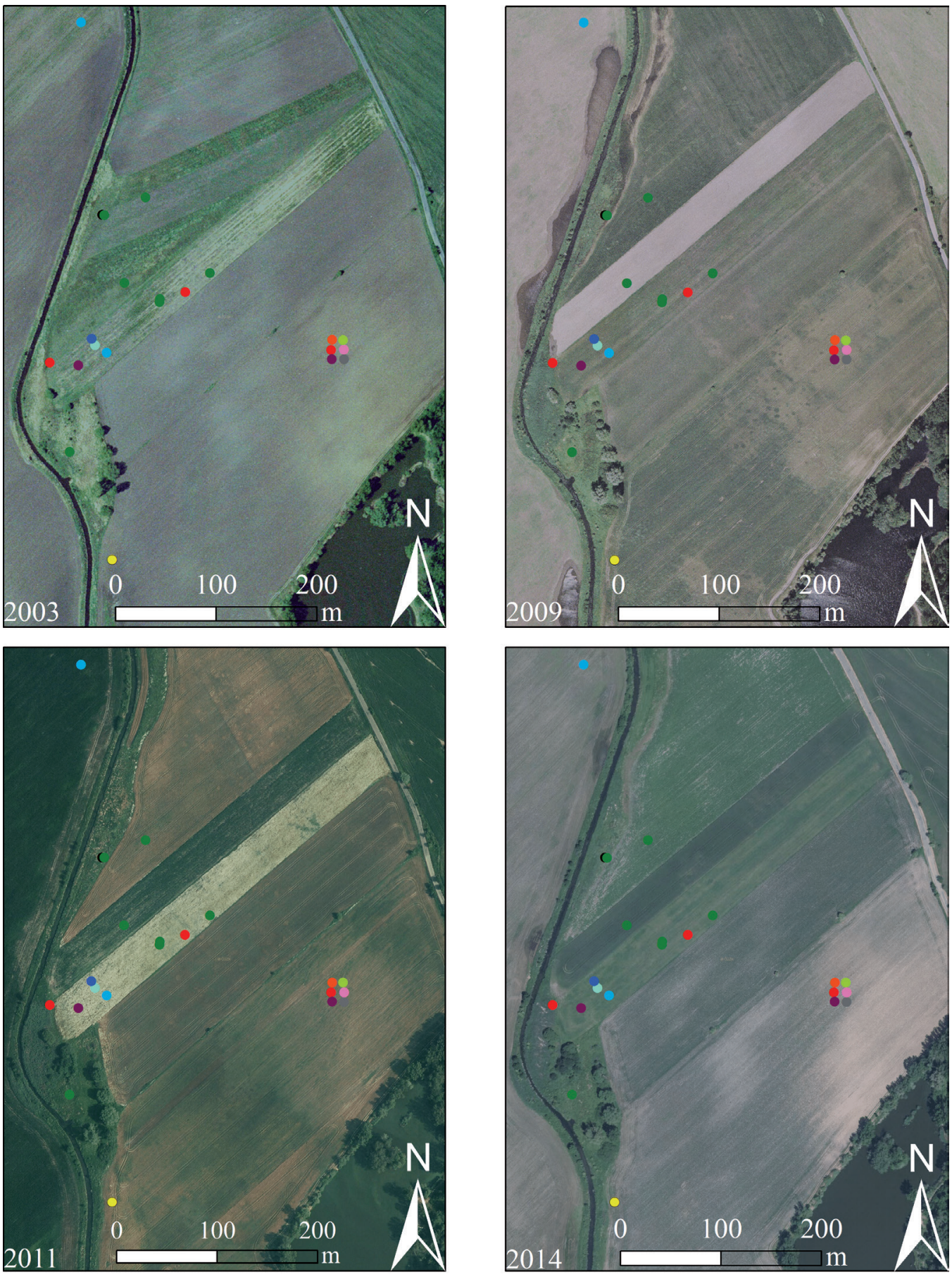

(

Mapa 9: Kostice / Lanžhot, poloha "Hvězda / Kostická váha," okres Břeclav. Satelitné snímky ČUZK.

Map 9: Kostice / Lanžhot, "Hvězda/ Kostická váha” site, Břeclav District. Satellite images, source: State Administration of Land Surveying and cadastre of Czech Republic (ČUZK). 


\begin{tabular}{|l|c|}
\hline \multicolumn{1}{|c|}{ Typ spôn } & Počet spôn \\
\hline A70/73 & 1 \\
\hline A84 & 2 \\
\hline Jobst 4F & 1 \\
\hline Bojović 21.3 & 1 \\
\hline Jobst 13C & 4 \\
\hline Jobst 13D & 1 \\
\hline Jobst 13E & 2 \\
\hline Riha 7.12 & 1 \\
\hline Riha 7.22 & 1 \\
\hline Spolu & 14 \\
\hline
\end{tabular}

Tab. 6: Spony z lokality Kostice / Lanžhot, poloha "Hvězda / Kostická váha."

Chart 6: Roman brooches from Kostice / Lanžhot, "Hvězda / Kostická váha” site, Břeclav district.

príznaky na snímkach ČUZK z roku 2009 a 2011 severne a západne od nálezov spôn zameraných pomocou GPS. Ide o pravidelné obdĺžnikové či štvorcové objekty, ktorých velkost̉ odpovedá možným zahĺbeným objektom sídliskového rázu, intervalovo datované do praveku - protohistórie. Na snímku spoločnosti Google z roku 2009 sú tieto príznaky viditel'né na celom poli medzi riekou a cestou 425, Břeclav-Lanžhot (Mapa 14). Na tomto mieste podnikol P. Milo geofyzikálne merania, pri ktorých sa podarilo dokázat prítomnost’ polykultúrnej lokality (Milo 2013, 730, obr. 23).

\section{Zhrnutie a závery}

Z vyššie uvedenej analýzy vyplýva niekol'ko záverov. Väčšina nálezov sa sústreduje na lavom brehu rieky Dyje. Nálezy z Mušova a Charvatské Nové Vsi odpovedajú predchádzajúcim nálezom, s výnimkou spôn typu Riha 5.9 (Obr.
3: 15; Obr. 6: 4) a doštičkovitej jazdeckej spony typu Riha 7.25 (Obr. 6: 5). Spony typu A84 a kolienkovité spony patria medzi fenomény horizontu markomanských vojen v oblasti, o čom svedčia aj najnovšie publikované nálezy z Mikulova (Kornhäuserová 2020, 26, 49).

A práve nálezy spôn západnej proveniencie, chronologicky dobre definovatel'né a zatial' pomerne nepočetné v danej oblasti môžu napomôct’ pochopit historické procesy. Väčšina nami skúmaných spôn západnej proveniencie je chronologicky definovaná fázou B1c, teda 2. pol. prvého storočia, či v prípade doštičkovitej jazdeckej spony Riha 7.25, tretej tretiny prvého storočia podla nálezov v Porýní (Rodge 2005, 161-162). Konečnou fázou výskytu je vo väčšine prípadov prvá tretina, či 1. pol. druhého storočia. Jedna z hypotéz môže predstavovat reorganizáciu limitu na prelome prvého a druhého storočia spolu s presunom légií zo západu počas vlády Domitiana a následne Trajána (Patek 1942, 130; Wheeler 2010, 1185-1227; Wheeler 

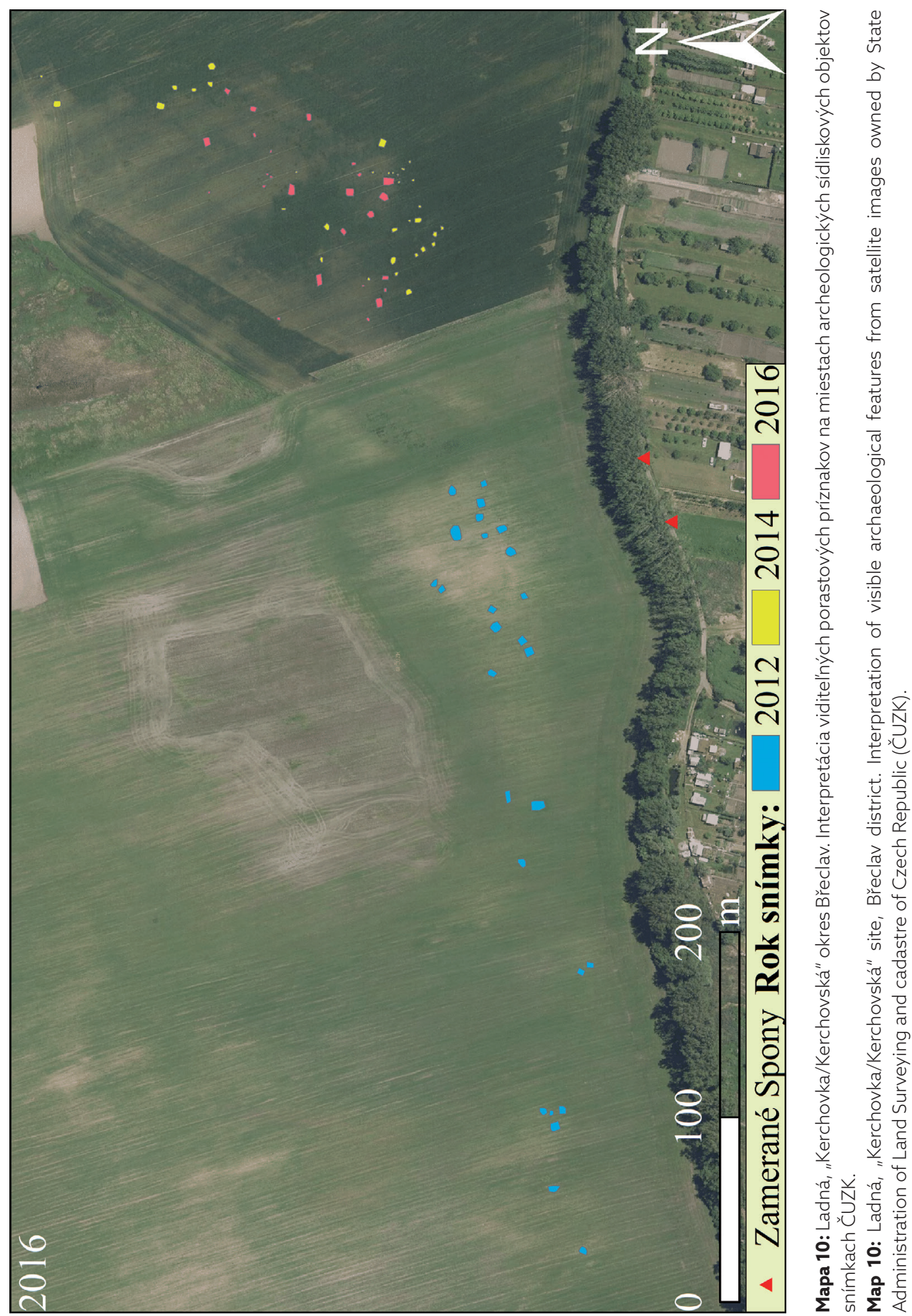
2011, 191-219). Spony sa odvtedy mohli rôznym spôsobom dostávat do nami sledovaného regiónu. Musíme ale pripomenút, že ide o ojedinelé nálezy, ktoré s presunom zároveň nemusia mat̉ nič spoločné. Druhou je možná účast̉ Germánov ako pomocných spriatelených zborov v rímskej armáde. Pre túto alternatívu svedčia aj nálezy výrazne členených spôn spolu s d’alšími početnými importmi na pohrebiskách juhozápadného Slovenska (Kolnik 1980; Bazouský 2005, 90; Jilek 2016). Tretou hypotézou môže byt prísun týchto spôn západnej proveniencie na zmienené lokality spolu s ostatnými nálezmi počas horizontu markomanských vojen B2/C1, napriek tomu, že ide o spony o niečo staršie.

Najstaršie nálezy radené do fázy B1b(?) registrujeme v obci Ladná a Milovice. Nálezy výrazne členených spôn typu A68/69 a typu A70/73 z Milovic, spolu s dosial' nie častou sponou typu A15 môžeme radit do prvého storočia, prípade do prvej tretiny storočia druhého. Osídlenie v polohe Ladná „Kerchovka/Kerchovská“ pretrváva počas prvého a druhého storočia. Poukazujú na to nález jedinej pravdepodobnej spony typu A67, nálezy spôn typu A84, a jed- nej kolienkovitej spony typu Jobst 13D. Osídlenie v katastri obce Lanžhot vykazovalo o niečo mladšie nálezy z prelomu fáz B1c až B2a do konca horizontu B2/C1, či počiatku stupňa C1, o čom svedčí rada kolienkovitých spôn, neskorých výrazne členených spôn typu A70/73 a typu A 84, panónskych trúbkovitých spôn typu A85 a spôn typu Jobst 4F, radiace sa do druhého storočia. Najmladšou lokalitou sa podla našich nálezov javí obec Rakvice, s nálezmi spôn typu Jobst 16C, patriacimi na počiatok 3. storočia.

Cielom štúdie bolo zverejnit a tým rozšrírit doterajšie poznatky o nové nálezy spôn a prispiet k ich interpretácii. Koordinovaný prístup poverených odborných inštitúcii a amatérskych zberačov môže priniest' d’alšie nové poznatky v d'alších rokoch. Lokality, z ktorých boli nami dokumentované nálezy zozbierané by si v budúcnosti zaslúžili d’alšiu vedeckú pozornosté. Nami študované spony boli len častou nálezov, ktoré boli z daných lokalít získané. Ďalšie výskumné metódy ako zbery, geofyzikálne merania či cielená sondáž môže priniest̉ precíznejšie poznatky o osídlení skúmaného regiónu v dobe rímskej.

1) Text článku vychádza z bakalárskej práce (Urban 2020), ktorá vznikla pod vedením PhDr. J. Jílka PhD. a bola obhájená na odd. klasické archeologie, ÚAM v roku 2020.

2) Na tomto mieste by som sa chcel pod’akovat riaditel’ovi Regionálneho Múzea v Mikulově Mgr. Petrovi Kubínovi a Mgr. Františkovi Trampotovi PhD. Za poskytnutie materiálu na spracovanie.

\section{Bibliografia}

Almgren, O. 1923: Studien über nordeuropäische Fibelformen der ersten nachchristlichen Jahrhunderte mit Berücksichtigung der provinzialrömischen und südrussischen Formen. Mannus-Bibliothek 32. Leipzig.

Andrzejowski, J. 1992: Strongly profiled brooches with triangular foot in the roman provinces and in barbaricum. In: Godłowski, K. (ed.), Probleme der Relativen und Absoluten Chronologie ab Latènezeit bis zum Frühmittelalter. Kraków, 111-120.
Andrzejowski, J. - Mistewicz A. - Prochowitz, R. 2009: Emaliowana zapinka z okolic Cieszkova na pólnocznym Mazowsku. In: Wróblewska, A. B. - Brzeziński, W. (eds.), Baltowie i ich sasiedzi. Marian Kaczyński in Memoriam. Warszawa: Państwowe Muzeum Archeologiczne w Warszawie, 657-685.

Bazovský, I. 2005: Spony z doby rímskej v slovenskom barbariku. Bratislava: Univerzita Komenského. Dizertačná práca.

Boelicke, U. 2002: Die Fibeln aus dem Areal der Colonia Ulpia Traiana. Xantener Berichte 10. Mainz.

Bojović, D. 1983: Rimske fibule Singidunuma. Beograd. 
Böhme, A. 1972: Die Fibeln der Kastelle Saalburg und Zugmantel, Saalburg-Jahrbuch XXIX, 5-112.

Cocis, S. 2004: Fibule Din Dacia Romana. The Brooches of Roman Dacia. Cluj-Napoca.

Čižmář M. 1980: Zjištovací výzkum laténskeho sídlište v poloze „Na pískách“ u Milovic. Přehled výzkumů 1977, 26.

Čižmář, M. - Rakovský I. 1980: Zpráva o povrchovém zběru v Milovicích. Přehled výzkumů 1977, 111.

Čižmář, M. - Čižmářová J. - Kejzlar, M. - Kolniková, E. 2009: Detektorová prospekce archeologických lokalit na Moravě v roce 2008. Přehled výzkumů 50, 139-152.

Čižmář, M. - Čižmářová J. - Kejzlar, M. - Kolniková, E. 2010: Detektorová prospekce archeologických lokalit na Moravě v roce 2009. Přehled výzkumů 51, 125-137.

Dąbrowska, T. 1994: Późne odmiany fibul silnie profilowanych v Polsce, Wiadomości Archeologiczne, t. LIII, 1993-1994, z. 1. 3-34.

Demetz, S. 1999: Fibeln der Spätlatène- und frühen römischen Kaiserzeit in den Alpenländern. Frühgeschichtliche und Provinzialrömische Archäologie. Materialien und Forschungen 4. Rahden/Westf.

Droberjar, E. 1997: Studien zu den germanischen Siedlungen der älteren römischen Kaiserzeit in Mähren. Fontes Archaeologici Pragenses, Volumen 21. Praha.

Droberjar, E. 1999: Dobřichov-Pičhora. Ein Brandgräberfeld der älteren römischen Kaiserzeit in Böhmen (Ein Beitrag zur Kenntnis der Marbod-Reiches). Fontes Archaeologici Pragenses, Volumen 23. Praha.

Droberjar, E. 2007: K interpretaci římských importů u českých Svébů v době Marobudově. In: Droberjar, D. - Chvojka O. (eds.), Archeologie barbarů 2006. Př́íspěvky z II. protohistorické konference České Budějovice, 21.-24. 11. 2006, Archeologické výzkumy v jižních Čechách - Supplementum 3. České Budějovice: Jihočeské muzeum v Českých Budějovicích, 41-91.

Droberjar, E. 2012: Ǩímské kolínkovité spony v Čechách, Archeologické výzkumy v jižních Čechách 25, 119-131.

Droberjar, E. 2016: Poznámky k nálezům římských spon na území Čech, Archeologie ve středních Čechách 20, 827-844.
Elschek, K. 2017: Rímske emailové spony zo Slovenska a nové nálezy emailových spôn zo Zohora. In: Droberjar, E. - Komoróczy, B. (eds.), Římské a germánské spony ve střední Evropě (Archeologie barbarů 2012). Brno: Archeologický ústav AV ČR Brno, 169-175.

Ettlinger, E. 1973: Die römischen Fibeln in der Schweiz. Bern.

Feugere, M. 1985: Les fibules en Gaule Méridionale de la Conquete á la fin du V s. apod. j.-C. Revues Archéologique Narbonnaise Supplément 12. Paris.

Filipová, M. - Harangozóová, E. 2014: Sídliště z doby římské v Hrušovanech u Brna (okr. Brno-venkov), Pravěk Nová řada 22, 257-311.

Fojtik, P. - Jilek, J. - Popelka, M. 2015: Roman medical instrument from the site of a short-term camp in Pravčice-Hulín in Central Moravia. In: A. Michałowski et al. (eds.), Viator per devia scientiae itinera. Archeologia nr 53. Poznań, 199-206.

Frýzl, J. 2016: Kímsko-provinciální spony z oblasti severně od středního Dunaje a jejich význam v tehdejší živé kultuře. Plzeň: Západočeská Univerzita v Plzni. Dizertační práce.

Gáspár, N. 2007: Die Keltischen und gallo-römischen Fibeln vom Titelberg. Dossiers d'archéologie du Musée National d'Histoire et d'Art XI. Luxembourg.

Gugl, Ch. 1995: Die römischen Fibeln aus Virunum. Klagenfurt.

Haralambieva, A. 1993: Provinzialrömische Kniefibeln aus Nordostbulgarien, Boulletin du Musee National de Varna 29, 87-99.

Jilek, J. 2009a: Dolní Bojanovice (okr. Hodonín). Přehled výzkumů 50, 318-319.

Jilek, J. 2009b: Josefov (okr. Hodonín). Přehled výzkumů 50, 325-326.

Jilek, J. 2009c: Prosiměrice (okr. Znojmo). Přehled výzkumů 50, 334-336.

Jilek, J. 2012: Bronzové nádoby z doby římské na Moravě a naddunajské části Dolního Rakouska. Pardubice.

Jilek, J. 2016: Roman Metal Vessels in the Milieu of Germanic Elites in the Middle Danube Region, Studia Hercynia XIX/1-2, 169-188.

Jilek, J. - Jiř́k, J. 2008: Dolní Bojanovice (okr. Hodonín). Přehled výzkumů 49, 341. 
Jilek, J. - Kuča, M. - Sojková, T. 2011: Pohřebiště z doby římské ve Velaticích, Slovenská Archeológia LX-2, 235-309.

Jobst, W. 1975: Die Römischen Fibeln aus Lauriacum. Forschungen in Lauriacum, Band 10. Linz.

Kolnik, T. 1980: Römerzeitliche Gräberfelder in der Slowakei. Archaeologica Slovaca. Fontes 14. Bratislava.

Kolniková, E. - Kolnik, T. 2004: Mince a spony - depot z neskorolaténskeho hradiska Rochovica pri Žiline, Slovenská Archeológia LII-1, 1-34.

Komoróczy, B. 1999: Zpráva o výzkumu fortifikace římského krátkodobého tábora a objektů sídliště z doby římské na lokalitě Mušov - Na pískách v letech 1995-1996. Přehled výzkumů 39, 165-196.

Komoróczy, B. 2008: Hradisko (Burgstall) u Mušova ve světle výzkumů v letech 1994-2007. In: Droberjar, E. - Komoróczy, B. - Vachůtová, D. (eds.), Barbarská sídliště, chronologické, ekonomické a historické aspekty jejich vývoje ve světle nových archeologických výzkumů (Archeologie barbarů 2007). Brno: Archeologický ústav AV ČR Brno, 391-438.

Komoróczy, B. - Rajtár, J. - Vlach, M. - Hüssen C. M. 2020: A companion to the archaeological sources of Roman military interventions into the germanic territory north of the Danube during the Marcomannic Wars. In: Erdrich, M. - Komoróczy, B. - Madejski P. - Vlach, M. (eds.), Marcomannic Wars and Antonine Plague. Selected essays on two disasters that shook the Roman world. Die Markomannenkriege und die Antoninische Pest. Ausgewählte Essays zu zwei Desastern, die das Römische Reich Erschütterten. Brno: Archeologický ústav AV ČR Brno, 173-254.

Komoróczy, B. - Vlach, M. - Zeliková, M. 2017: Dokumentace, publikace a interpretace detektorových nálezů na příkladu spon Jobst F4. In: Droberjar, E. - Komoróczy, B. (eds.), Ř́mské a Germánské spony ve střední Evropě (Archeologie barbarů 2012). Brno: Archeologický ústav AV ČR Brno, 31-57.

Komoróczy, B. - Vlach, M. - Zeliková, M. - Sedláček, J. - Růžičková, P. 2019: Revize stavu archeologických komponent v trati Drnholec „Holenická pole“ pomocí prospekčních a málo invazivních výzkumných metod. Přehled výskumů 60-2, 9-56.
Kornhäuserová, V. 2020: Chronologická a prostorová distribuce nálezů spon doby římské na sídlišti v Mikulově. Brno: Masarykova Univerzita. Bakalářská diplomová práce.

Koščević, R. 1980: Antičke fibule s područja Siska. Zagreb.

Kubin, P. 2002: Ǩímskoprovinciální spony starší doby římské z Moravy a naddunajské části dolního Rakouska. Praha: Univerzita Karlova. Magisterská diplomová práce.

Kuzmová, K. - Rajtár, J. eds. 2010: Rímsky kastel v Iži, Výskum 1978-2018. Archaeologica Slovaca Monographiae. Nitra: Archeologický ústav SAV Nitra.

Lamiová-Schmiedlová, M. 2003: Spony s emailovou výzdobou z doby rímskej z Hrabušíc, Musaica 24, 43-50.

Maczyńska, M. 2001: Das Verbreitungsbild der Fibeln A67/68 und A.68 im Barbaricum, Slovenská Archeológia XLIX, 165-179.

Matouschek J. - Nowak H. 1981-1982: Unpublizierte Hasen- und Hundefibeln aus Österreichischen Privatsammlungen. Mit einem Nachtrag: Pferdeund Ritterfibeln, Römisches Österreich, Jahgang 9/10, 131-182.

Milo, P. 2013: Geofyzikálne prieskumy včasnostredovekých sídliskových lokalít na dolnom Podyjí - Geophysical investigations of early medieval occupation sites in the lower Dyje (Thaya) river region, Archeologické rozhledy LXV-2013, 706-734.

Ortisi, S. - Pröttel, M. P. 2002: Römische Kleinfunde aus Burghöfe 2. Frühgeschichtliche und Provinzialrömische Archäologie, Band 6. Leidorf.

Patek, E. 1942: Verbreitung und Herkunft Der römischen Fibeltypen in Pannonien. Dissertationes Pannonicae. Budapest.

Pecinouská, M. 2008: Provinciální spony starší doby římské v Čechách. Praha: Univerzita Karlova v Praze. Magisterská diplomová práce.

Peškaŕ, I. 1972: Fibeln aus der römischen Kaiserzeit in Mähren. Praha: Academia.

Phillipe, J. 2000: Les fibules de Seine-et-Marne du 1er siecle av. J.-C. au 5e siecle ap. J.-C. Mémoires archéologiques de Seine-et-Marne n 1. 1999. Nemours.

Pieta, K. 2019: Early Roman Period Burials of Púchov culture: Buried Natives or offered foreigner? Slovenská archeológia LXVII/2, 241-284. 
Rajtár, J. 2014: Stíp Marca Aurelia a archeologické doklady o rímskych výpravách proti Kvádom. In: Stíp Marca Aurelia a stredné Podunajsko. Zb. SNM, Archeológia, Suppl. 8, Bratislava, 107-140.

Riha, E. 1979: Die Römischen Fibeln aus Augst und Kaiseraugst. Forschungen in Augst, Band 3. Augst. Riha, E. 1994: Die Römischen Fibeln aus Augst und Kaiseraugst. Die Neufunde seit 1975. Forschungen in Augst, Band 18. Augst.

Rodge, M. 2005: Zeldzame $3^{\mathrm{de}}$-eeuwse fibula vane en paard met ruiter uit de vicus Velzeke (Oost-Vlaanderen). Een bijdrage tot de typo-chronologie, iconografie en interpretatie van de Provinciaal-Romeinse ruiterfibulae. In: Archeologische Kronik Van Zuid-Oost-Vlaanderen. Bijdragen IX. Overdruk uit Handelingen XII. 115-147.

Říhovský, J. 1951: Hroby z římského období u Mikulova, Archeologické rozhledy III/1951, 37-40.

Sedlmayer, H. 1995: Die römischen Fibeln von Wels. Sonderreihe zum Jahrbuch des Musealvereines Wels, Band 4. Wels.

Sedlmayer, H. 2009: Die Fibeln vom Magdalensberg. Funde der Grabungsjahre 1948-2002 und Altfunde des 19. Jahrhunderts. Archäologische Forschungen zu den Grabungen auf dem Magdalensberg 16. Klagenfurt am Wörthersee.

Schmid, S. 2010: Die römischen Fibeln aus Wien. Wien.

Tejral, J. 1960: Sídliště z doby římské z Lanžhota, okr. Břeclav. Přehled výzkumů 1959, 171.

Tejral, J. 1967: Nové nálezy na římsko-barbarském sídlišti u Lanžhota, okr. Břeclav. Přehled výzkumů 1966, 39.

Tejral, J. 1970a: Počátky doby římské na Moravě z hlediska hrobových nálezů. Študijné Zvesti 18.

Tejral, J. 1970b: Nález sídlištního objektu z pozdní doby římské v Lanžhotě, okr. Břeclav. Přehled výzkumů 1968, 36-37.

Tejral, J. 1970c: Sídlištní objekt z Ladné (okr. Břeclav). Přehled výzkumů 1968, 36, 99.

Tejral, J. 1971: Dva nové objekty na sídlišti z doby římské u Ladné (okr. Břeclav). Přehled výzkumů 1969, 19-20, 63-64.
Tejral, J. 1974: Další výzkumy na sídlišti z doby římské v Ladné (okr. Břeclav). Přehled výzkumů 1973, 53-54, 186-189.

Tejral, J. 1977: Zachraňovací výzkum v písečníku u obce Ladná, okr. Břeclav. Přehled výzkumů 1975, 43-44.

Trampota, F. 2016: Milovice (K. Ú. Milovice u Mikulova, okr. Břeclav). Přehled výzkumů 57-1, 249.

Urban, P. 2020: Rímskoprovinciálne spony z Mikulovskej oblasti nájdené detektormi kovov. Brno: Masarykova univerzita. Bakalárska práca.

Vlach, M. 2008: Římsky krátkodobý tábor a nové nálezy z doby římské z Charvatské Nové Vsi In: Droberjar, E. - Komoróczy, B. - Vachůtová, D. (eds.), Barbarská sídliště, chronologické, ekonomické a historické aspekty jejich vývoje ve světle nových archeologických výzkumů (Archeologie barbarů 2007). Brno: Archeologický ústav AV ČR Brno, 461-468.

Vlach, M. 2010: Žárové pohřebiště v Šitbořicích a přilehlý region v době římské. Magisterská diplomová práce. Ústav archeologie a muzeologie. Masarykova Univerzita. Brno.

Wheeler, E. L. 2010: Rome's Dacian Wars: Domitian, Trajan and Strategy on the Danube, Part I, The Journal of Military History 74, 1185-1227.

Wheeler, E. L. 2011: Rome's Dacian Wars: Domitian, Trajan and Strategy on the Danube, Part II, The Journal of Military History 75, 191-219.

Zeliková, M. 2019: Sídliště stř̌ední doby římské v Jevišovce a jeho postavení v kontextu osídlení soutoku Jevišovky a Dyje. Brno: Masarykova Univerzita. Magisterská diplomová práce.

Zeman, T. 2017a: Střední Pomoraví v době římské. Svědectví povrchové prospekce. Olomouc: Univerzita Palackého v Olomouci.

Zeman, T. 2017b: Př́́spěvek k poznání nejstaršího germánského osídlení Moravy optikou nových povrchových nálezů, Slovenská Archeológia LXV, 279-319. 


\section{New metal detector prospection finds of provincial roman brooches from south Moravia collected in Regional Museum in Mikulov.}

Most types of roman provincial brooches documented and analyzed in our article have been previously known in the past research of river Thaya region. We examined finds of 67 provincial roman brooches of which 30 did not have any GPS coordinates thus it is impossible to use its data for an exact spatial analysis. 5 brooches had missing GPS coordinates, but a cadastral location and 3 brooches had missing both GPS coordinates and cadastral location. In a case of Rakvice village all 5 brooches found had missing both GPS coordinates and cadastral location. This is an unfortunate state as it is not so uncommon for metal detecting amateurs, non-archaeologists to take surveys without cooperation with professional archaeologist nor using the right methodology of survey. Most numerous group of brooches is a group of 29 strongly profiled brooches of Almgren 68, 69 and $70 / 73$ types dated across the first century AD and the first quarter of second century AD. Second most numerous group is a group of 24 Knee brooches of Jobst 13 type widely known as a roman military brooches of second half of the second century AD, mainly during the Marcomannic wars in the 166 - 180 AD until the end of second century and the beginning of third century AD. 4 brooches of Jobst 16C type are chronologically late dated in the first half of the third century AD. These brooches are also the latest brooches in our examined collection. Two finds were of Almgren A85 type brooches, plate brooches of Riha 7.22 and Riha 7.25 type, and two zoomorphic brooches. One brooch was found of the enameled brooch of Exner I 32 type and a brooch of Riha 5.9 type. These rare brooches are of western provincial origin and well dated to the last thirty years of the first century $\mathrm{AD}$ and on. Most of brooches were found in the left bank of river Thaya. Few brooches were said to be found at the roman temporary camps at Charvatská Nová Ves, Mušov - Na pískách and at main military station at Mušov - Burgstall. However, these Brooches had missing GPS information. This must be considered in the overall evaluation. Two important archaeological sites had been re-discovered comparing satellite images by Google and by State Administration of Land Surveying and cadastre of Czech Republic (ČUZK) with GPS coordinates of our metal finds near Ladná and Lanžhot villages, district Břeclav. Satellite images had shown probable archaeological features in the proximity of measured group of brooches spatially dispersed in the area. These features mirror sunken huts typical for Germanic and Slavic occupation in wider area during Roman period and Early-Middle Ages. Both locations Ladná "Kerchovka/Kerchovská" and Lanžhot "Hvězda-Kostická váha" had been known in the past but neglected since the rescue excavations in the 1960s. Further research of archaeological features at these locations would be an important step in the research of Roman period in the studied area. These brooches could have been imported in the region directly either by Roman soldiers during the wars with Germanic tribes along the Danube in the beginning of the second century AD during reign of Domitian and Trajan, and during Marcomannic wars. They could have also been brought to the Germanic territory by local Germanic warriors fighting against/alongside Romans as enemies/allies as auxiliaries. Strongly profiled brooches of the Pannonian origin could have been part of a regional traditional dress since they are nowadays found extensively with the spread of metal detecting surveys in the whole Moravia. This new evidence has changed previous view of strongly profiled brooches of roman provincial origin of the first century AD. Other types of Roman imports such as bronze vessels and samian ware corelates with our hypotheses. 


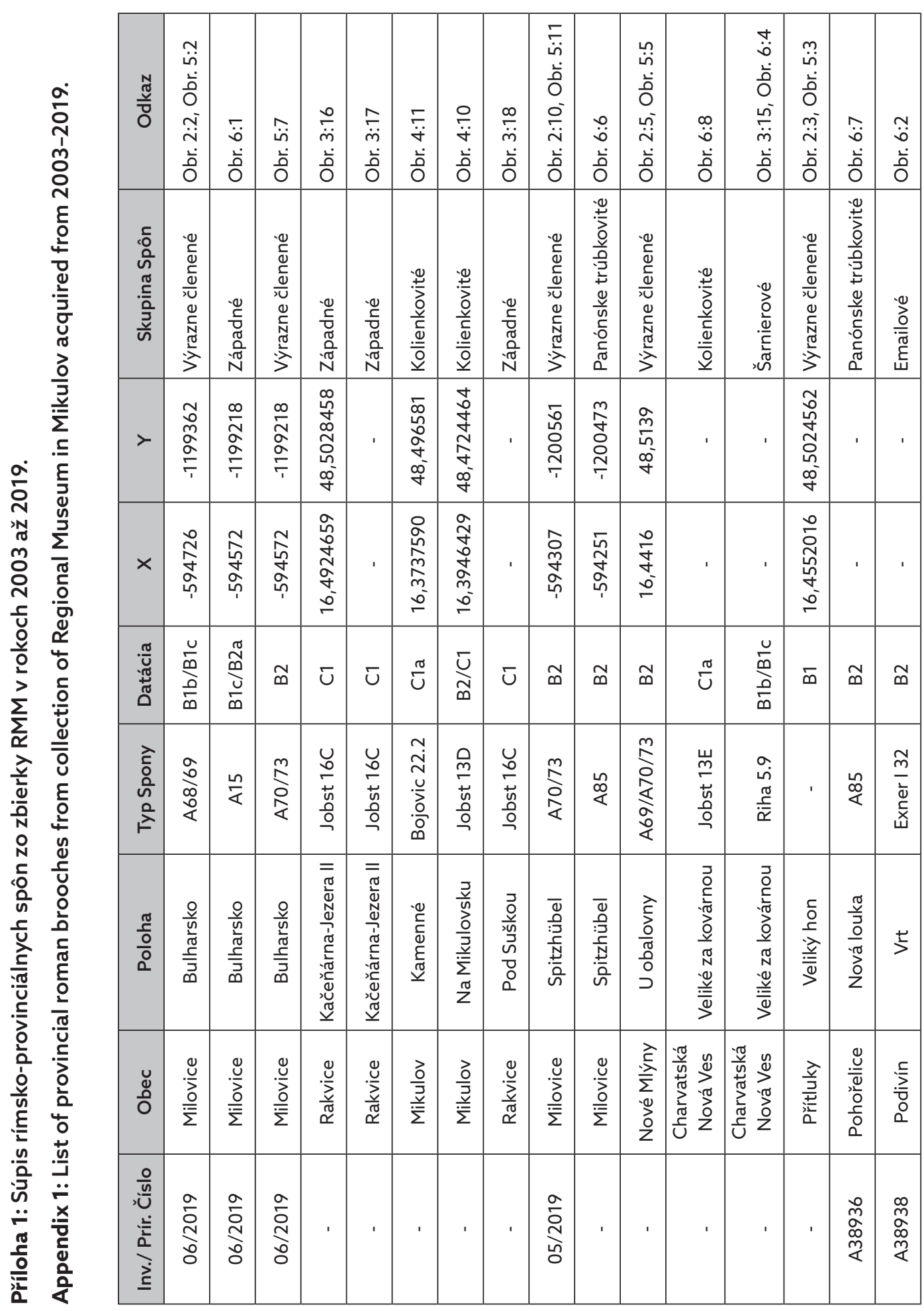




\begin{tabular}{|c|c|c|c|c|c|c|c|c|c|c|c|c|c|c|c|c|c|c|}
\hline 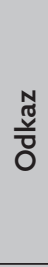 & $\begin{array}{l}\hat{y} \\
\dot{+} \\
\stackrel{0}{0}\end{array}$ & 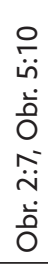 & $\begin{array}{l}\ulcorner \\
\ddot{+} \\
\stackrel{\circ}{0}\end{array}$ & 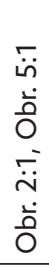 & 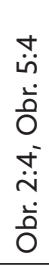 & $\begin{array}{l}\stackrel{\sigma}{\dot{N}} \\
\stackrel{\overline{0}}{0}\end{array}$ & $\begin{array}{l}m \\
\ddot{0} \\
\stackrel{m}{0} \\
0\end{array}$ & $\begin{array}{l}\stackrel{\sim}{+} \\
\dot{0}\end{array}$ & $\begin{array}{l}m \\
\stackrel{\leftrightarrow}{+} \\
\stackrel{े}{0}\end{array}$ & $\begin{array}{l}\stackrel{+}{+} \\
\stackrel{0}{0} \\
0\end{array}$ & 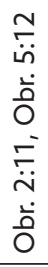 & $\begin{array}{l}\check{m} \\
\dot{0} \\
\dot{0}\end{array}$ & $\begin{array}{l}\stackrel{N}{m} \\
\stackrel{\leftrightarrow}{0} \\
\stackrel{0}{0}\end{array}$ & 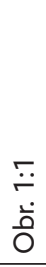 & $\begin{array}{l}\stackrel{m}{\ddot{m}} \\
\stackrel{\circ}{\circ} \\
\stackrel{0}{0}\end{array}$ & 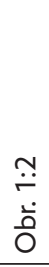 & , & $\begin{array}{l}\stackrel{m}{\stackrel{m}{\circ}} \\
\text { Oे }\end{array}$ \\
\hline 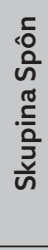 & 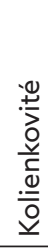 & 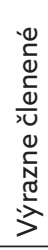 & 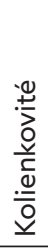 & 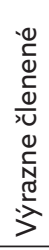 & 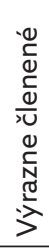 & 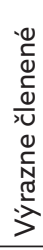 & 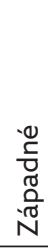 & 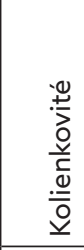 & 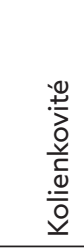 & 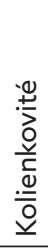 & 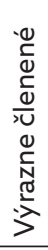 & 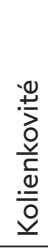 & 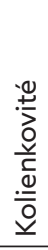 & 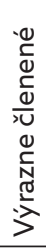 & 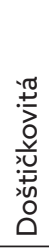 & 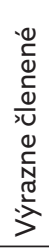 & 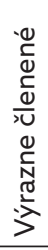 & 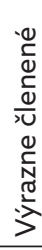 \\
\hline$\succ$ & 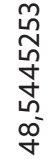 & ' & ' & ' & \begin{tabular}{l}
$\hat{\omega}$ \\
$\stackrel{N}{\sim}$ \\
\multirow{+}{*}{} \\
$\infty$ \\
+
\end{tabular} & ' & 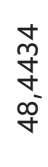 & $\begin{array}{l}\stackrel{+}{+} \\
\text { m } \\
+ \\
+ \\
\text { - } \\
+\end{array}$ & 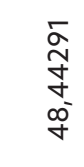 & 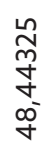 & ' & 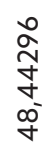 & \begin{tabular}{l} 
o \\
\multirow{+}{+}{} \\
+ \\
$\infty$ \\
+
\end{tabular} & 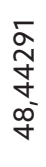 & 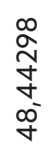 & 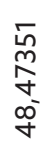 & ' & 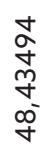 \\
\hline$x$ & 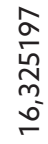 & ' & ' & ' & 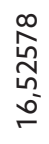 & ' & 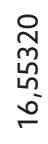 & $\begin{array}{l}\bar{N} \\
\text { Nh} \\
\stackrel{0}{0} \\
\stackrel{0}{0}\end{array}$ & 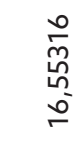 & 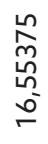 & ' & 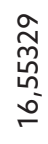 & 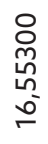 & 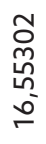 & $\begin{array}{l}\underset{N}{N} \\
\text { గn } \\
\stackrel{0}{0} \\
\stackrel{0}{0}\end{array}$ & $\begin{array}{l}\text { N } \\
\text { ஸे } \\
\text { గ̂ } \\
\stackrel{0}{0}\end{array}$ & ' & 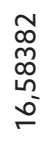 \\
\hline 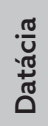 & 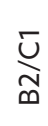 & 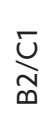 & 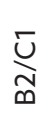 & $\frac{u}{\infty}$ & $\stackrel{0}{\infty}$ & $\underset{\infty}{\bar{\infty}}$ & $\bar{U}$ & $\underset{\varpi}{\bar{U}}$ & 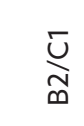 & 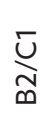 & $\widetilde{\varnothing}$ & $\frac{\pi}{U}$ & $\frac{\pi}{U}$ & 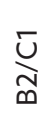 & $\frac{u}{\infty}$ & 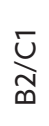 & $\frac{u}{\frac{u}{0}}$ & $\frac{0}{\infty}$ \\
\hline 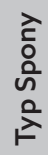 & 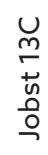 & 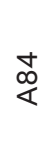 & 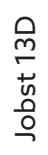 & 产 & $\hat{\circ}$ & $\underset{\leftarrow}{\mathbb{\infty}}$ & 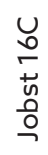 & 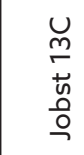 & 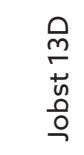 & $\begin{array}{l}u \\
\text { m } \\
\stackrel{\tilde{n}}{0} \\
\stackrel{0}{0}\end{array}$ & $\frac{m}{\stackrel{n}{o}} \frac{1}{<}$ & 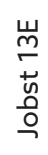 & 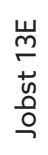 & 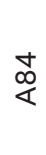 & $\begin{array}{l}\stackrel{N}{N} \\
\frac{\sigma}{c} \\
\frac{c}{\alpha}\end{array}$ & $\underset{\leftarrow}{+\infty}$ & $\begin{array}{l}a \\
0 \\
\infty \\
0 \\
0\end{array}$ & $\begin{array}{l}\infty \\
0 \\
\end{array}$ \\
\hline$\frac{\text { ㅇ }}{\frac{0}{0}}$ & 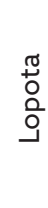 & $\frac{\frac{\partial}{30}}{\frac{10}{\Sigma}}$ & $\begin{array}{l}\frac{\pi}{0} \\
\frac{0}{0} \\
\frac{0}{v} \\
\frac{v}{\omega}\end{array}$ & 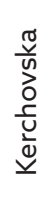 & 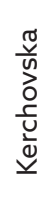 & $\begin{array}{l}\frac{\pi}{v} \\
\frac{0}{0} \\
\frac{0}{u} \\
\frac{v}{\omega}\end{array}$ & 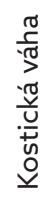 & 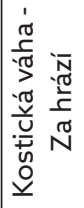 & 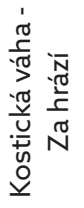 & 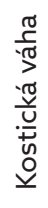 & ' & $\begin{array}{l}\frac{\pi}{N} \\
\text { N } \\
\text { I }\end{array}$ & $\begin{array}{l}\frac{\pi}{N} \\
\text { N } \\
\stackrel{N}{1}\end{array}$ & ' & $\begin{array}{l}\overbrace{N}^{\pi} \\
\stackrel{N}{X} \\
\text { I }\end{array}$ & 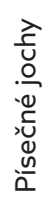 & ' & $\begin{array}{l}\vec{v} \\
\text { Dे } \\
0 \\
0 \\
0 \\
0\end{array}$ \\
\hline $\begin{array}{l}\text { هั } \\
\text { Oे }\end{array}$ & $\begin{array}{l}\frac{\widehat{v}}{2} \\
\frac{-\pi}{0} \\
\frac{1}{0} \\
0 \\
0 \\
0\end{array}$ & $\begin{array}{l}\frac{\partial}{\vec{z}} \\
\frac{\overrightarrow{\underline{z}}}{\Sigma}\end{array}$ & 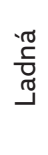 & 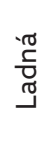 & 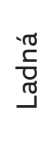 & $\begin{array}{l}\frac{\pi}{\tilde{T}} \\
\frac{0}{\sigma} \\
\end{array}$ & $\begin{array}{l}\stackrel{0}{u} \\
\stackrel{0}{\tilde{\omega}} \\
\stackrel{0}{0}\end{array}$ & 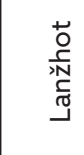 & 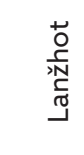 & 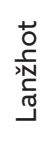 & 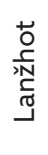 & $\begin{array}{l}\stackrel{0}{u} \\
\stackrel{v}{\omega} \\
\underline{0}\end{array}$ & $\begin{array}{l}\stackrel{0}{u} \\
\stackrel{+}{*} \\
\underline{0}\end{array}$ & $\begin{array}{l}\stackrel{0}{u} \\
\stackrel{n}{n} \\
\stackrel{0}{v}\end{array}$ & $\begin{array}{l}\stackrel{0}{u} \\
\stackrel{0}{\tilde{n}} \\
\underline{0}\end{array}$ & 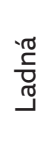 & 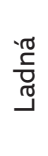 & 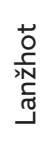 \\
\hline 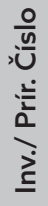 & \begin{tabular}{l}
0 \\
\multirow{\alpha}{\alpha}{} \\
$\infty$ \\
$\stackrel{m}{<}$
\end{tabular} & $\begin{array}{l}\bar{\delta} \\
\stackrel{\circ}{\alpha} \\
\stackrel{m}{<}\end{array}$ & 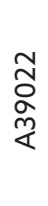 & 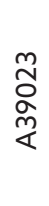 & 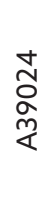 & 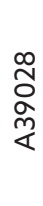 & 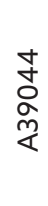 & 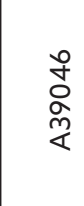 & $\begin{array}{l}\text { f } \\
\text { ○े } \\
\text { 玄 }\end{array}$ & $\begin{array}{l}\overline{1 n} \\
\stackrel{\alpha}{\circ} \\
\stackrel{m}{<}\end{array}$ & $\begin{array}{l}\text { 今ે } \\
\text { مे } \\
\text { mे }\end{array}$ & \begin{tabular}{l}
$\hat{O}$ \\
员 \\
$\dot{\alpha}$ \\
\multirow{4}{*}{}
\end{tabular} & 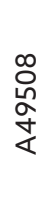 & 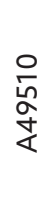 & $\begin{array}{l}\frac{0}{10} \\
\frac{\alpha}{+}\end{array}$ & \begin{tabular}{l}
$\stackrel{0}{N}$ \\
مू \\
\multirow{2}{*}{}
\end{tabular} & \begin{tabular}{l} 
त \\
مू \\
\multirow{2}{*}{}
\end{tabular} & $\begin{array}{l}\bar{m} \\
\stackrel{\alpha}{\alpha} \\
\frac{\alpha}{+}\end{array}$ \\
\hline
\end{tabular}




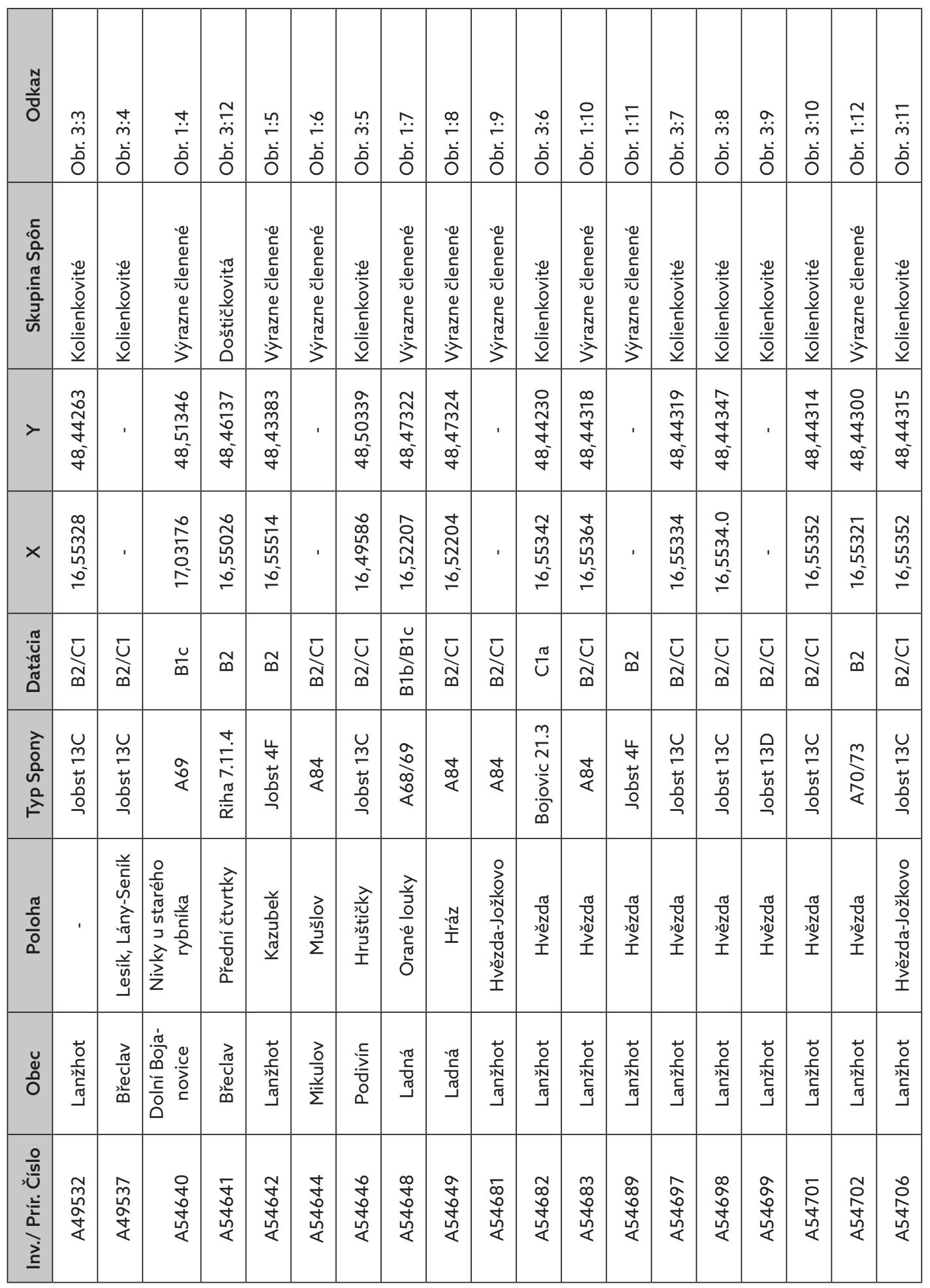




\begin{tabular}{|c|c|c|c|c|c|c|c|c|c|c|c|c|c|c|}
\hline $\begin{array}{l}\text { तु } \\
\text { एँ } \\
\text { Oे }\end{array}$ & $\begin{array}{l}+ \\
\ddot{m} \\
\dot{0} \\
0\end{array}$ & $\begin{array}{l}\stackrel{m}{r} \\
\stackrel{\circ}{0} \\
\text { Oे }\end{array}$ & 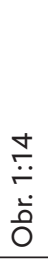 & 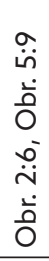 & 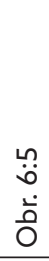 & $\begin{array}{l}\stackrel{\leftrightarrow}{+} \\
\dot{\forall} \\
\stackrel{\circ}{0} \\
0\end{array}$ & $\begin{array}{l}\stackrel{+}{+} \\
\stackrel{+}{0} \\
0\end{array}$ & 1 & $\begin{array}{l}\infty \\
\dot{0} \\
\dot{0} \\
\stackrel{0}{0} \\
\infty \\
\dot{\sim} \\
\dot{\sim} \\
\dot{0} \\
0\end{array}$ & $\begin{array}{l}\stackrel{N}{\dddot{+}} \\
\stackrel{2}{0} \\
\text { Oे }\end{array}$ & 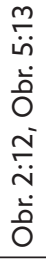 & 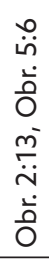 & $\begin{array}{l}\stackrel{\infty}{\dot{+}} \\
\stackrel{\circ}{0} \\
\stackrel{0}{O}\end{array}$ & $\begin{array}{l}\stackrel{a}{\dot{\forall}} \\
\stackrel{\circ}{\circ} \\
\stackrel{0}{0}\end{array}$ \\
\hline 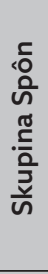 & $\begin{array}{l}\frac{0}{U} \\
\frac{\pi}{0} \\
\frac{\pi}{N}\end{array}$ & 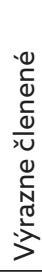 & 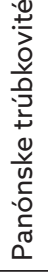 & 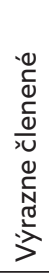 & $\begin{array}{l}\frac{\pi}{U} \\
\frac{\pi}{2} \\
\frac{\pi}{N}\end{array}$ & 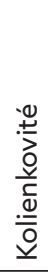 & 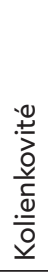 & 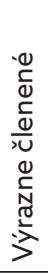 & 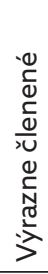 & 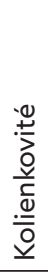 & 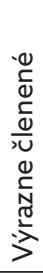 & 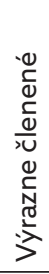 & 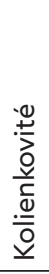 & 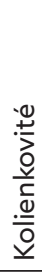 \\
\hline$\succ$ & 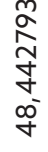 & ' & ' & ' & ' & ' & ' & ' & ' & ' & ' & I & ' & ' \\
\hline$\times$ & 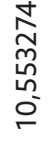 & ' & ' & ' & ' & ' & ' & ' & ' & ' & ' & ' & ' & ' \\
\hline $\begin{array}{l}\frac{\pi}{\mathscr{J}} \\
\stackrel{\pi}{\pi} \\
0\end{array}$ & 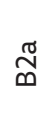 & $\frac{u}{\frac{u}{\infty}}$ & $\widetilde{\infty}$ & 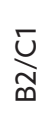 & $\frac{u}{\infty}$ & 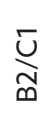 & 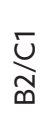 & $\frac{\frac{u}{m}}{\frac{\tilde{m}}{\infty}}$ & 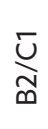 & $\frac{\pi}{U}$ & 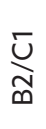 & $\bar{\infty}$ & $\underset{\varpi}{\bar{\varpi}}$ & $\underset{\varpi}{\bar{\nu}}$ \\
\hline 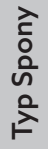 & $\begin{array}{l}\underset{N}{N} \\
\frac{\sigma}{c} \\
\frac{\tilde{\alpha}}{\alpha}\end{array}$ & $\begin{array}{l}0 \\
0 \\
\infty \\
0 \\
0\end{array}$ & $\stackrel{\substack{\infty \\
\ll}}{<}$ & 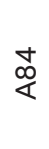 & 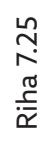 & 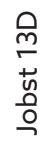 & $\begin{array}{l}u \\
\stackrel{m}{\Gamma} \\
\stackrel{n}{n} \\
\stackrel{0}{0} \\
\stackrel{0}{n}\end{array}$ & 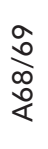 & $\underset{<}{+}$ & 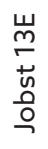 & 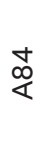 & I & $\begin{array}{l}\stackrel{0}{m} \\
\stackrel{+}{n} \\
\stackrel{0}{0} \\
\stackrel{0}{n}\end{array}$ & $\begin{array}{l}\text { m} \\
\text { ஸे } \\
\stackrel{0}{0} \\
\stackrel{0}{2}\end{array}$ \\
\hline$\frac{\pi}{\frac{0}{0}}$ & $\begin{array}{l}\underset{N}{\mathbb{N}} \\
\text { N } \\
\text { I }\end{array}$ & 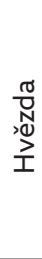 & 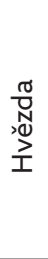 & 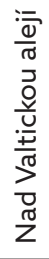 & 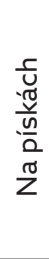 & 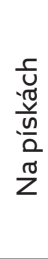 & $\begin{array}{l}\frac{\sigma}{-} \\
\frac{\pi}{v} \\
\frac{n}{a} \\
\frac{\pi}{Z} \\
Z\end{array}$ & ' & $\begin{array}{l}\widehat{v} \\
\frac{1}{d} \\
\frac{0}{N} \\
0 \\
\frac{0}{0} \\
0 \\
0\end{array}$ & $\begin{array}{l}\widehat{v} \\
\frac{1}{d} \\
\stackrel{0}{N} \\
\frac{0}{0} \\
0 \\
0 \\
0\end{array}$ & 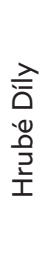 & 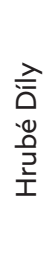 & 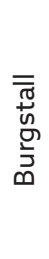 & 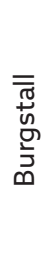 \\
\hline $\begin{array}{l}\text { U } \\
\text { Oे }\end{array}$ & 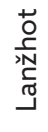 & 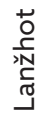 & $\begin{array}{l}\stackrel{+}{0} \\
\frac{a}{N N} \\
\stackrel{N}{J} \\
\end{array}$ & $\frac{\frac{\partial}{\vec{z}}}{\frac{\overrightarrow{\underline{z}}}{\Sigma}}$ & 总 & 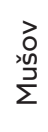 & 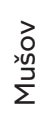 & 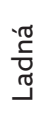 & 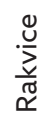 & 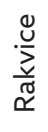 & $\begin{array}{l}\frac{\widehat{v}}{\frac{\text { wn }}{2}} \\
\frac{\grave{1}}{2}\end{array}$ & $\begin{array}{l}\frac{\vec{v}}{\frac{\text { nn }}{2}} \\
\frac{\text { In }}{2}\end{array}$ & 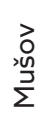 & 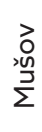 \\
\hline 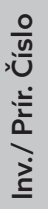 & $\begin{array}{l}\text { Oे } \\
\text { 守 } \\
\text { 岁 }\end{array}$ & $\begin{array}{l}\stackrel{0}{8} \\
\text { \& } \\
\text { L }\end{array}$ & $\begin{array}{l}\text { Oे } \\
\text { 㐫 } \\
\text { 这 }\end{array}$ & 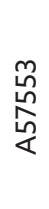 & $\begin{array}{l}0 \\
\text { o } \\
\frac{1}{2} \\
\frac{1}{\alpha}\end{array}$ & 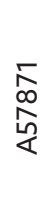 & $\begin{array}{l}\stackrel{N}{\infty} \\
\text { L } \\
\stackrel{\text { Ln }}{<}\end{array}$ & 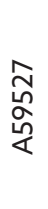 & 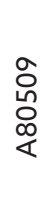 & 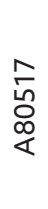 & \begin{tabular}{l} 
స్ \\
م⿱ \\
\multirow{4}{\alpha}{}
\end{tabular} & $\begin{array}{l}\bar{n} \\
\text { مٌ } \\
\infty \\
\&\end{array}$ & 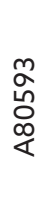 & 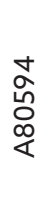 \\
\hline
\end{tabular}




\section{Bc. Patrik Urban}

- Ústav archeologie a muzeologie,

Filozofická fakulta, Masarykova univerzita,

A. Nováka 1, 60200 Brno, Česká republika

463482@mail.muni.cz 
